PNL-7693

UC-903

\title{
Water-Table Elevations on the Hanford Site, 1990
}
D. R. Newcomer
K. D. Pohlod
J. P. McDonald

June 1991

Prepared for the U.S. Department of Energy under Contract DE-AC06-76RLO 1830

Pacific Northwest Laboratory Operated for the U.S. Department of Energy by Battelle Memorial Institute 


\title{
DISCLAIMER
}

This report was prepared as an account of work sponsored by an agency of the United States Government. Neither the United States Government nor any agency thereof, nor Battelle Memorial Institute, nor any of their employees, makes any warranty, expressed or implied, or assumes any legal liability or responsibility for the accuracy, completeness, or usefulness of any information, apparatus, product, or process disclosed, or represents that its use would not infringe privately owned rights. Reference herein to any specific commercial product, process, or service by trade name, trademark, manufacturer, or otherwise does not necessarily constitute or imply its endorsement, recommendation, or favoring by the United States Government or any agency thereof, or Battelle Memorial Institute. The views and opinions of authors expressed herein do not necessarily state or reflect those of the United States Government or any agency thereof.

\author{
PACIFIC NORTHWEST LABORATORY \\ operated by \\ BATTELLE MEMORIAL INSTITUTE \\ for the \\ UNITED STATES DEPARTMENT OF ENERGY \\ under Contract DE-ACO6-76RLO 1830
}

Printed in the United States of America

Available to DOE and DOE contractors from the

Office of Scientific and Technical Information, P.O. Box 62, Oak Ridge, TN 37831; prices available from (615) $576-8401$. FTS $626-8401$.

Available to the public from the National Technical Information Service, U.S. Department of Commerce, 5285 Port Royal Rd., Springfield, VA 22161. 
PNL -7693

UC -903

WATER-TABLE ELEVATIONS ON THE HANFORD SITE, 1990

D. R. Newcomer

K. D. Pohlod

J. P. McDonald

June 1991

Prepared for the U.S. Department of Energy under Contract DE-ACO6-76RL0 1830

Pacific Northwest Laboratory Richland, Washington 99352 

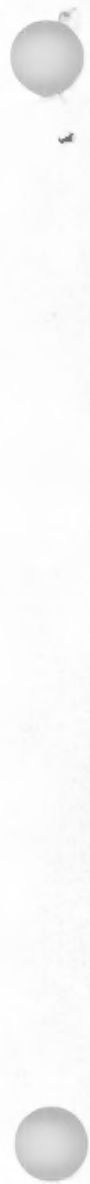


\section{SUMMARY}

The Pacific Northwest Laboratory prepared water-table maps of the U.S. Department of Energy's Hanford Site for June 1990 from water-level elevations measured in 224 wells across the Hanford Site. The greatest changes in the elevation of the water table at Hanford occurred beneath the decommissioned U Pond, 200-East Area, the 100-N Area, the 1100 and 3000 Areas, and near the Columbia River. The elevation of the ground-water mound beneath the decommissioned $U$ Pond continued to decline, decreasing as much as $0.8 \mathrm{~m}$ $(2.6 \mathrm{ft}$ ) between December 1989 and December 1990. This decline has been observed in wells in much of the adjacent 200-West Area and is primarily the result of continued dissipation of the ground-water mound beneath $U$ Pond since it was deactivated in 1984 .

The elevation of the water table beneath the $100-\mathrm{N}$ Area declined as much as $1.9 \mathrm{~m}$ (6.2 ft) between December 1989 and December 1990 . This decline in the water table is primarily the result of decreasing volumes of wastewater discharged to the 1324-N/NA and 1325-N liquid waste disposal facilities in the 100-N Area.

The elevation of the water table beneath the 200-East Area decreased approximately $0.3 \mathrm{~m}(1 \mathrm{ft})$ between December 1989 and December 1990. This response is primarily attributed to decreasing wastewater discharged to varjous ponds, cribs, and trenches in the 200 Areas. However, the elevation of the ground-water mound beneath B Pond, which is located east of the 200-East Area and continues to receive wastewater, did not change significantly between December 1989 and December 1990.

In the 1100 and 3000 Areas, the elevation of the water table responded primarily to pumping and recharge by the city of Richland's well field and ground-water recharge basin system during 1990. The water tables beneath the 1100 and 3000 Areas are also influenced by river stage and irrigation practices.

The water table near the Columbia River, including the 300 Area, responded significantly to the rise in the river stage during runoff events in June 1990 and between November and December 1990. 

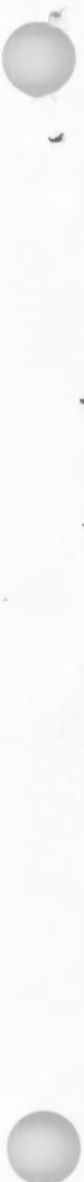

. 


\section{CONTENTS}

SUMMARY ..................................

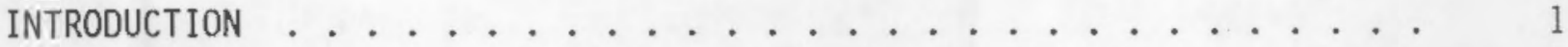

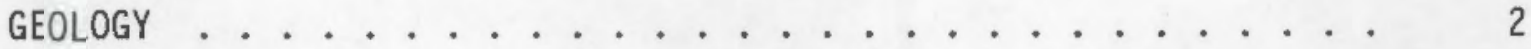

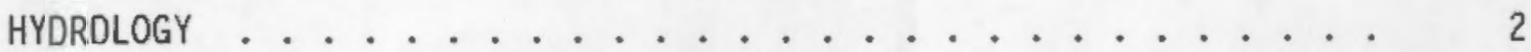

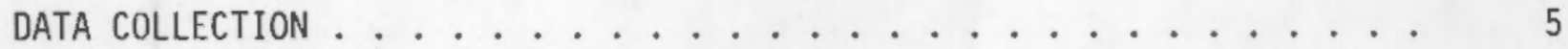

DATA UNCERTAINTY ............................... 6

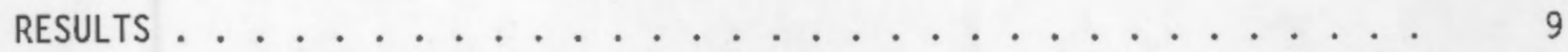

HANFORD SITE WATER-TABLE FEATURES ............. 9

CHANGES IN THE HANFORD SITE WATER TABLE DURING $1990 \ldots \ldots$

B Pond ................................ 11

U Pond .......................... 15

$100-\mathrm{N}$ Area .......................... 17

300 Area .................... . . . 19

1100 and 3000 Areas ......................... 24

SUMMARY AND CONCLUSIONS .......................... 27

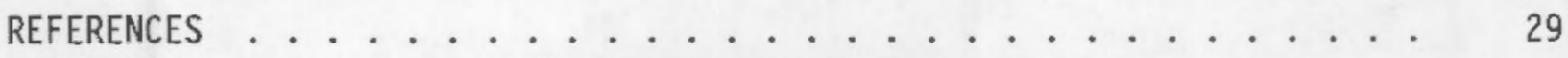

APPENDIX A - WATER-LEVEL MEASUREMENTS FOR THE HANFORD SITE, JUNE $1990 \ldots \ldots \ldots$. . . . . . . . . . . . . .

APPENDIX B - WATER-LEVEL MEASUREMENTS FOR THE HANFORD SITE, DECEMBER 1990 . . . . . . . . . . . . . . B.1

APPENDIX C - WATER-LEVEL MEASUREMENTS AT SPECIFIC HANFORD

SITE AREAS, JUNE 1990 . . . . . . . . . . . . . C.1 

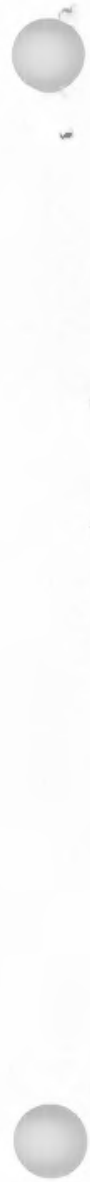


\section{FIGURES}

1 Hanford Site Location Map ............... 3

2 Hydrographs of Wel1s 699-66-91, 699-66-103, and 699-72-88 Between June 1990 and July $1990 \ldots \ldots$. . . . . . . . 12

3 Map of the Water Table Influenced by B Pond, June 1990 . . . . . 13

4 Hydrographs of Wells 699-39-39, 699-40-39, 699-41-40, and $699-42-40 \mathrm{~B} \ldots \ldots \ldots . \ldots . \ldots . \ldots 14$

5 Water-Table Map of the Area Beneath the Decommissioned U Pond in the 200-West Area for June $1990 \ldots . . \ldots 16$

6 Hydrograph of Well 299-W18-21 ............. 18

7 Hydrograph of Well 299-W7-1 . . . . . . . . . . . . 18

8 Water-Table Map Beneath the 1325-N Liquid Waste Disposal Facility in the 100-N Area for June 1990 . . . . . . . . 19

9 Hydrographs of Wells 699-81-58, 199-N-27, and 199-N-60 .... 20

10 Water-Table Map Beneath the 300,1100 , and 3000 Areas for June $1990 \ldots \ldots . \ldots . \ldots . \ldots 21$

11 Hydrograph of Well 399-8-1 . . . . . . . . . . . . 23

12 Hydrograph of Well 699-S40-E14 ............ 25

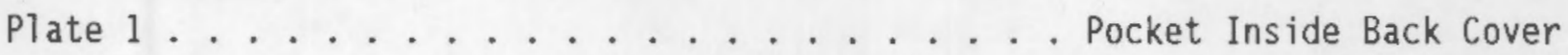



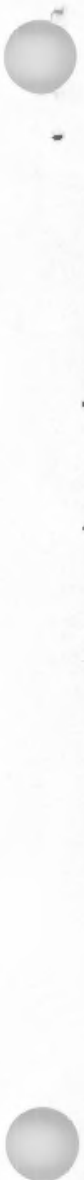

-
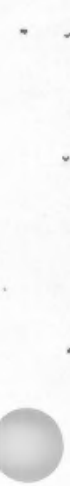


\section{INTRODUCTION}

The Site Characterization and Assessment Section, Environmental Sciences

Department, of the Pacific Northwest Laboratory $(P N L){ }^{(a)}$ prepares water-table maps of the Hanford Site. Production of these maps supports the Ground-Water Environmental Surveillance Program, which is sponsored by the U.S. Department of Energy (DOE).

Water levels in selected wells open to the unconfined aquifer on the Hanford Site are traditionally measured in June and December of each year. The purpose of these measurements is to determine the changes in the configuration of the water table to assess the physical impact of wastewater disposal on ground-water flow.

Water-leve1 measurements can be used to construct a water-table map that represents the elevation of the water-table surface. This map can be used to infer general directions of ground-water flow, particularly in the upper part of the aquifer. Ground water moves from regions of higher water potentials to regions of lower water potentials perpendicular to contours of equal potential, assuming conditions of isotropic hydraulic conductivities. Water-table maps can be used to

- identify recharge and discharge areas

- evaluate the physical influence of wastewater discharges on groundwater flow directions

- determine the potential for water movement between adjacent groundwater and surface water bodies

- determine the horizontal hydraulic gradient and estimate the average linear velocity of ground-water flow

- improve the design of the water-level monitoring well network.

Also, water-level data used to construct water-table maps are required to calibrate ground-water models.

(a) The Pacific Northwest Laboratory is operated for the U.S. Department of Energy by Battelle Memorial Institute. 
In addition to water levels measured in wells distributed across the Hanford Site, water levels were also measured from five specific areas within Hanford. Included are areas around the decommissioned 216-U-10 Pond (U Pond), 216-B-3 Pond (B Pond), 100-N Area, 1100 and 3000 Areas, and 300 Area. The locations of these areas are shown in Figure 1. Water-table maps of these areas are intended to enhance the definition of the water-table configuration beneath wastewater discharge facilities that may impact ground-water flow. Water-level measurements and a water-table elevation map for December 1989 were presented in Newcomer and McDonald (1990). Semiannual water-level measurements and a water-table map of the Separations Areas for December 1989 and June 1990 are presented in Kasza (1990) and Kasza et a7. (1990), respectively. Historical water-level data and an evaluation of past changes to the watertable surface are presented in Zimmerman et al. (1986) and Newcomer (1990).

Water-levels are measured in wells that monitor the upper part of the unconfined aquifer. The wells used to measure water-levels were chosen based on geologic and hydrologic information available for Hanford. A summary of the geology and hydrology of the Hanford Site follows.

\section{GEOLOGY}

The Hanford Site lies within the Pasco Basin, one of many topographic and structural basins within the Columbia Plateau. Principal geologic units beneath the Hanford Site include, in ascending order, the Columbia River Basalt Group, the Ringold Formation, and a series of deposits informally referred to as the Hanford formation. These units are covered locally by no more than a few meters of recent alluvial or windblown deposits. 01der geologic units have been deformed into a series of roughly east-west trending folds.

\section{HYDROLOGY}

Both confined and unconfined aquifers are present beneath the Site. The confined aquifers lie primarily within the Columbia River basalts. The unconfined aquifer lies in river and lake deposits of the Ringold Formation and 


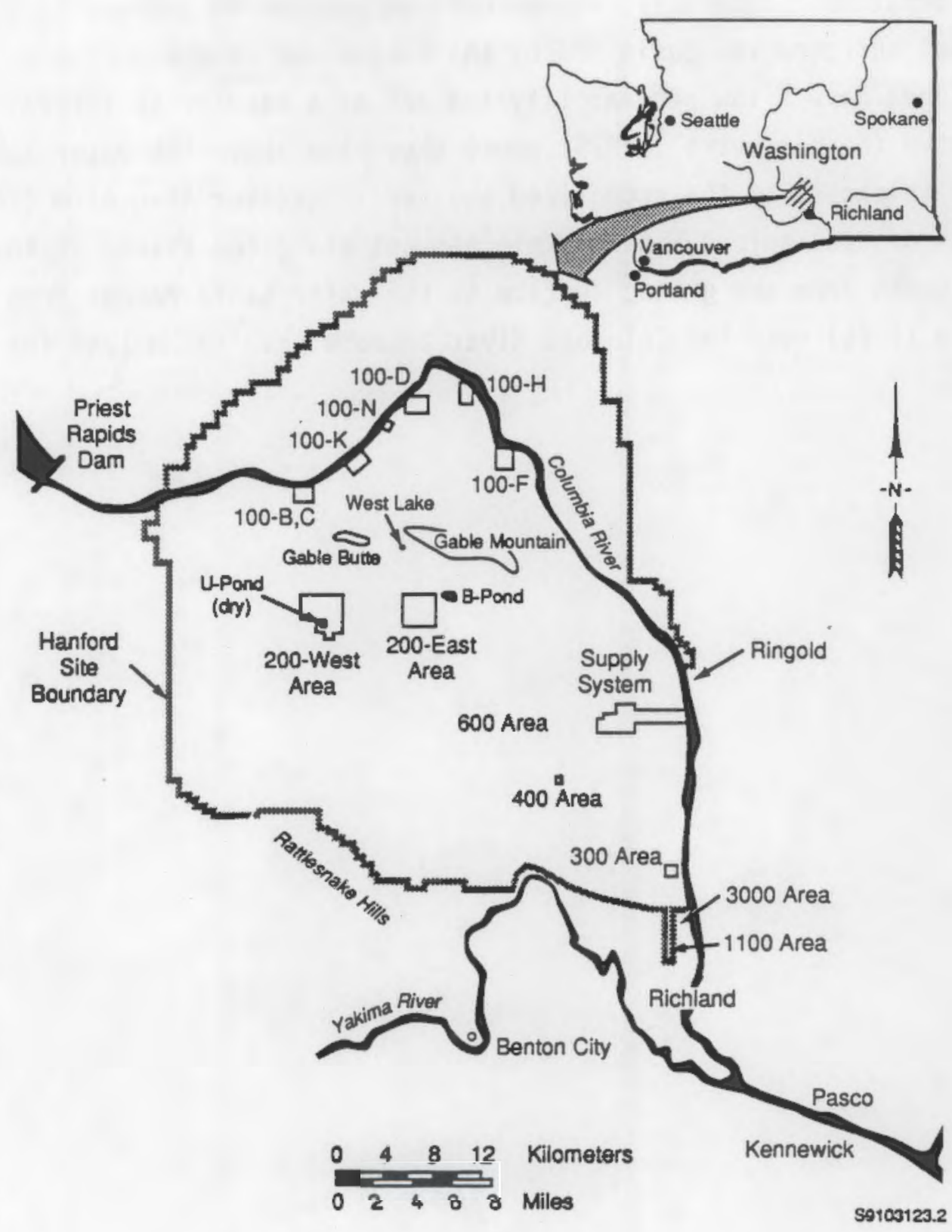

FIGURE 1. Hanford Site Location Map

glaciofluvial sediments of the Hanford formation, as well as some more recent alluvial sediments in areas adjacent to the Columbia River (Gephart et al. 1979).

The unconfined aquifer is bounded below by either the basalt surface or, in places, the relatively impervious clays and silts of the lower unit of the 
Ringold Formation. Laterally, the unconfined aquifer is bounded by the basalt ridges that surround the basin and by the Yakima and Columbia rivers. The basalt ridges have a low permeability and act as a barrier to lateral flow of ground water (Gephart et al. 1979) where they rise above the water table. The saturated thickness of the unconfined aquifer is greater than $61 \mathrm{~m}(200 \mathrm{ft})$ in some areas of the Hanford Site and pinches out along the flanks of the basalt ridges. Depth from the ground surface to the water table ranges from less than $0.3 \mathrm{~m}$ ( $1 \mathrm{ft}$ ) near the Columbia River to more than $106 \mathrm{~m}$ (348 ft) near the 200 Areas. 


\section{DATA COLLECTION}

During June 1990 water levels were measured in 224 wells completed in the unconfined aquifer. Additional measurements were taken in 117 wells, also completed in the unconfined aquifer, near U Pond, B'Pond, the 100-N Area, 1100 Area, and the 300 Area. The number of wells in which water-level measurements were taken was reduced in December 1990. During December 1990 water levels were measured in 66 selected wells across the Hanford Site to determine water-level changes between December 1989 and December 1990. A water-table map for December 1990 was not constructed because past maps indicate that the configuration of the water table relative to the scale of the Hanford Site does not change significantly over a 6 -month period.

Most monitoring wells at the Hanford Site used for water-level measurement are 15 or $20 \mathrm{~cm}$ ( 6 or $8 \mathrm{in.)}$ in diameter and are constructed of steel casing. Several small-diameter [5-cm (2-in.)] piezometers and some larger diameter wells are also used. Wells constructed for Resource Conservation and Recovery Act (RCRA) ground-water monitoring are 10 or $15 \mathrm{~cm}$ (4 or 6 in.) in diameter. Monitoring wells used to measure water levels for the unconfined aquifer are completed with well screens or perforated casing generally open to the upper 3 to $6 \mathrm{~m}$ (10 to $20 \mathrm{ft}$ ) of the aquifer. This type of completion allows measurements representative of the water-table elevation. Well locations for water-level monitoring are shown in Plate 1 (inside back cover).

A written procedure developed in accordance with the techniques described in ASTM (1988), EPA (1986), Garber and Koopman (1968), and USGS (1977) was followed to measure water levels in piezometers and wells across the Hanford Site, including the specific area around the decommissioned U Pond (PNL 1989). Westinghouse Hanford Company used the procedure in WHC (1989) to measure water levels in areas around B Pond, and in the 100-N Area, 1100 and 3000 Areas, and 300 Area. Both PNL and WHC use a calibration well to standardize the steel tapes, but PNL uses only those standardized steel tapes for measuring water levels that deviate in length from the calibrated steel tape by less than $0.10 \mathrm{ft}( \pm 0.10 \mathrm{ft})$. Whereas $W H C$ applies a correction, based on a proportion 
of the depth-to-water between the measured well and the calibration well, to the depth-to-water measurement, no matter what the deviation is between the standardized steel tape and the calibrated tape.

According to the water-level measurement procedure described in PNL (1989), a chalked, standardized steel tape was used to measure the depth to the water surface in units of feet from a surveyed measuring point. These measurements were repeated to confirm the initial value. If the second measurement differed by more than $0.02 \mathrm{ft}$ from the first, the water level was remeasured until two measurements within this tolerance were obtained. Measurements were compared to previous measurements of depth to water to provide a check for gross errors.

Elevation of the water-table was determined by subtracting the depth-towater measurement from the surveyed measuring point elevation marked on the well casing. The reference for all measuring point elevations is mean sea level. The elevation of the water-table surface, $S$, can be expressed as

$$
S=E-D
$$

where $S=$ elevation of the water-table surface above mean sea level

$E=$ elevation of surveyed measuring point above mean sea level

$D=$ depth to the water-level surface in the piezometer or we11, measured below the surveyed measuring point.

All depth-to-water measurements are conducted within a 3-week period to minimize the effects of long-term changes in water-level.

\section{DATA UNCERTAINTY}

All water-level measurements for June 1990 and December 1990 are collected within respective 3 -week periods. The greatest short-term water-leve 1 changes that occur within this period are in wells influenced by the rise and fall of the Columbia River stage. This may cause some variability in the location of the water-table contours adjacent to the river. Other minor 
uncertainties in the water-level measurements are caused by effects from diurnal changes (e.g., barometric effects, earth tides), deviations from the vertical installation of wells, errors in the elevation of the surveyed measuring points, and errors within the measuring tolerances of the field equipment. 



\section{RESULTS}

Water levels measured during June 1990 and December 1990 are listed in Appendixes A and B, respectively. Water levels measured during June 1990 for specific areas within the Hanford Site are listed in Appendix 'C. The Hanford Site water-table map, presented in Plate 1 , was constructed by hand-contouring the values for the June 1990 water-table elevations. The contours in Plate 1 are in units of meters. To allow the map to be more easily read, the prefixes have been omitted from all well numbers shown on the map. Well numbers in the 100 Areas have the prefix 199, well numbers in the 200-East and 200 -West Areas have the prefix 299, well numbers in the 300 Area have the prefix 399, and well numbers in the 600 Area have the prefix 699.

\section{HANFORD SITE WATER-TABLE FEATURES}

The following are important features of the Hanford Site water-table map:

- Water-table elevations generally decrease from west to east across the Hanford Site south of Gable Mountain and Gable Butte.

- Water-table elevations decrease northward through the gap between Umtanum Ridge and Gable Butte and the gap between Gable Butte and Gable Mountain.

- The hydraulic gradient of the water table decreases abruptly between the 200-West and 200-East Areas.

- The water level in the Yakima River is of higher elevation than that of the water table in the adjacent region of the Hanford Site.

- Ground-water mounds are present beneath B Pond, the location of decommissioned U Pond, and the 1100 Area.

Elevated water levels in the western region of the Hanford Site may be attributable to ground-water recharge in Cold Creek and Dry Creek valleys and on the adjacent ridges (i.e., Yakima, Umtanum, and Rattlesnake Ridges). The source of recharge is most likely infiltration of rain and snow at the higher elevations and offsite irrigation of agricultural land at the lower elevations. 
Water-table elevation generally decreases toward the Columbia River at the eastern edge of the Hanford Site and north of the Gable Mountain-Gable Butte anticline, implying discharge of unconfined ground water to the Columbia River along the Hanford reach. The Hanford reach is the free-flowing stretch of the Columbia River between Priest Rapids Dam' and the city of Richland.

The abrupt change in the hydraulic gradient of the water table between the 200-West and 200-East Areas is attributed to an increase in the hydraulic conductivity of the sediments from west to east (Graham et al. 1981).

The elevation of the water table in the region between the Yakima River, near Horn Rapids Dam, and the Columbia River is lower than the Yakima River stage, which is approximately $122 \mathrm{~m}(400 \mathrm{ft}$ ) above mean sea level. This implies that unconfined ground water is being recharged by the Yakima River. Water levels measured in this region also indicate that ground water recharged by the Yakima River flows to the east beneath the southern portion of the Hanford Site and discharges to the Columbia River.

Ground-water mounds beneath B Pond and the decommissioned U Pond have been caused by process cooling water and other liquid wastes recharging the ground water at those locations. A summary of wastewater discharges to disposal facilities in the 200 Areas is presented by Brown et al. (1990). The ground-water mound beneath the 1100 Area has been caused by recharge from the city of Richland's recharge infiltration basins.

\section{CHANGES IN THE HANFORD SITE WATER TABLE DURING 1990}

The greatest change to the water table at Hanford between December 1989 and December 1990 (the reporting period) occurred beneath the decommissioned $\mathrm{U}$ Pond in the 200-West Area, beneath the 1325-N Liquid Waste Disposal Facility in the 100-N Area, and along the Hanford reach of the Columbia River. Wastewater recharging the ground water at the 200-West and 100-N Areas has caused large ground-water mounds. Wastewater discharges to cribs, trenches, and ponds in the 200-East and 300 Areas have also impacted the ground water. A summary of wastewater discharges to disposal facilities in the 200 and 600 Areas for 1989 is presented by Brown et al. (1990). 
The elevation of the water table beneath the 200 Areas declined during the reporting period. The water table declined approximately $0.3 \mathrm{~m}$ ( $1 \mathrm{ft}$ ) beneath the 200-East Area and as much as $0.8 \mathrm{~m}(2.6 \mathrm{ft})$ beneath the 200 -West Area. These declines are primarily attributed to 1) an overall decrease in wastewater discharged to various cribs, trenches, and ponds in the 200 Areas and 2) continued dissipation of the ground-water mound beneath $U$ Pond since it was decommissioned in 1984. The decrease in wastewater discharge corresponds to the shutdown of production facilities in the 200 Areas.

Water-level changes also occurred in wells near the Columbia River. Water-level measurements indicate that the water table rose as much as $2.3 \mathrm{~m}$ (7.5 ft) along the Columbia River between December 1989 and June 1990. These changes are primarily the result of bank storage effects caused by the rise of the river stage. Hydrographs showing the influence of the river stage on the unconfined aquifer at various locations along the Columbia River are presented in Jensen (1987), Liikala et al. (1988), Schalla et a1. (1988), and Fruland and Lundgren (1989). The Columbia River stage changes in response to releases at the Priest Rapids Dam upstream from the Hanford reach and to seasonal influences. Examples of water-level responses thought to be influenced by river stage fluctuations are shown in Figure 2 for wells 699-66-91, 699-66-103, and 699-72-88. These wells are located west of the 100-B and 100-C Areas north of Umtanum Ridge and Gable Butte. A hydrograph of the river stage at the nearest gauging station, located approximately 4 miles downstream at the 100-N Area, is also shown in Figure 2.

B Pond

A map of the water table influenced by B Pond, presented in Figure 3 , indicates that ground water flows radially from beneath $B$ Pond. The elevation of the water table did not change significantly between December 1989 and December 1990, except for the water level observed in well 699-39-39. Hydrographs of wells 699-39-39, located southeast of B Pond, 699-42-40B, located at the center of the ground-water mound, and 699-40-39 and 699-41-40, located between wells 699-39-39 and 699-42-40B around the perimeter of 216-B-3C Pond, are presented in Figure 4 . 

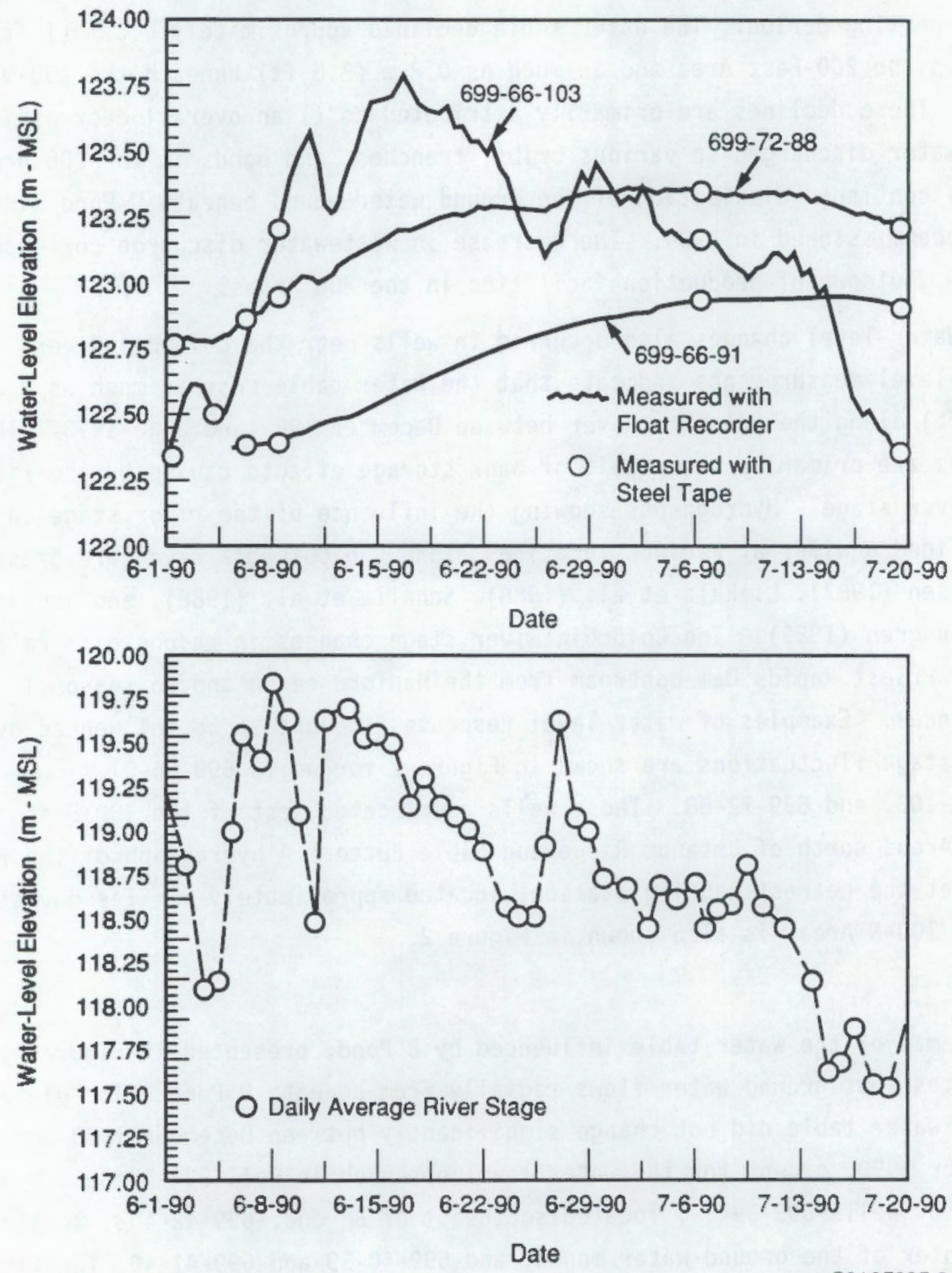

FIGURE 2. Hydrographs of Wel1s 699-66-91, 699-66-103, and 699-72-88 Between June 1990 and July 1990 


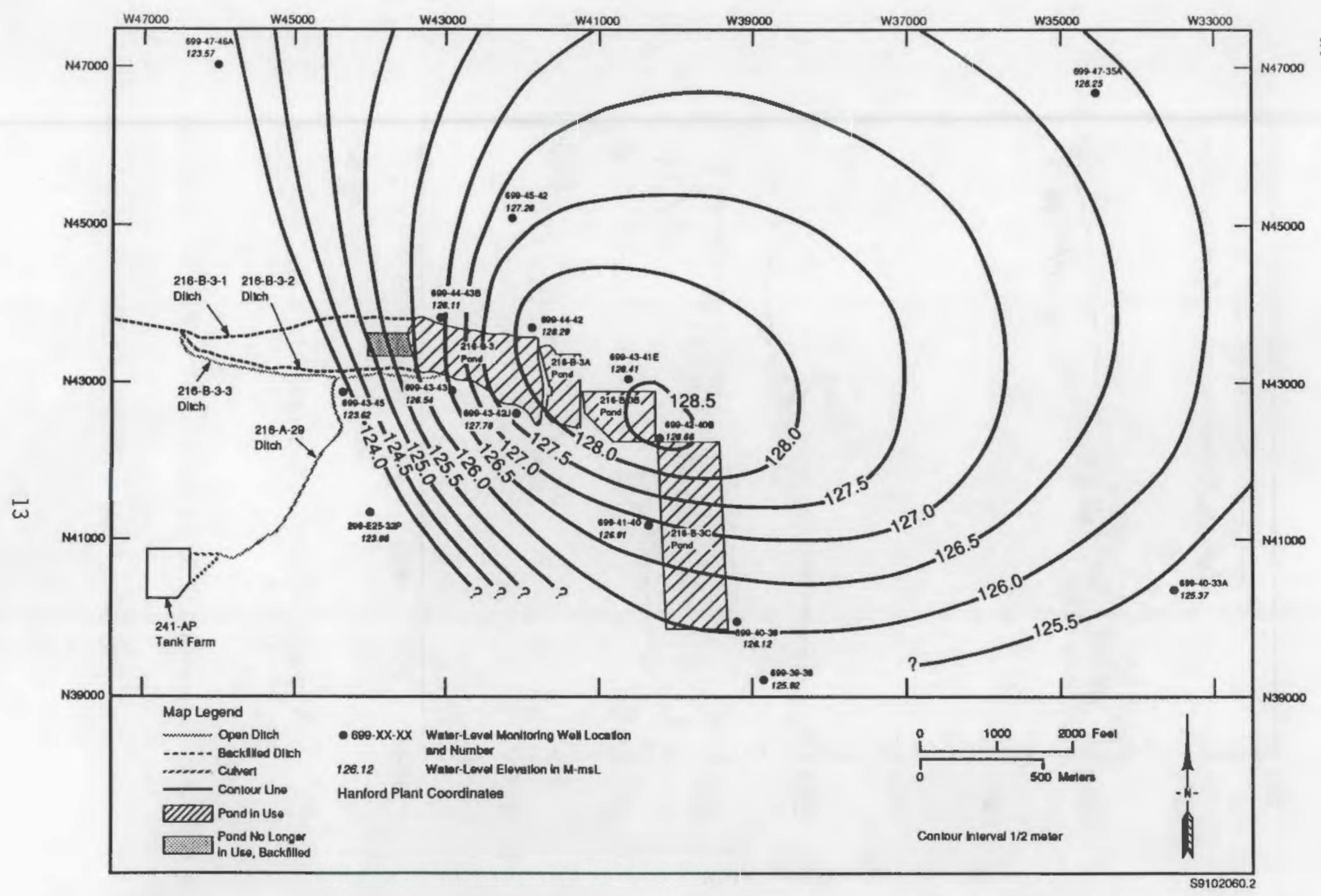

FIGURE 3. Map of the Water Table Influenced by B Pond, June 1990 


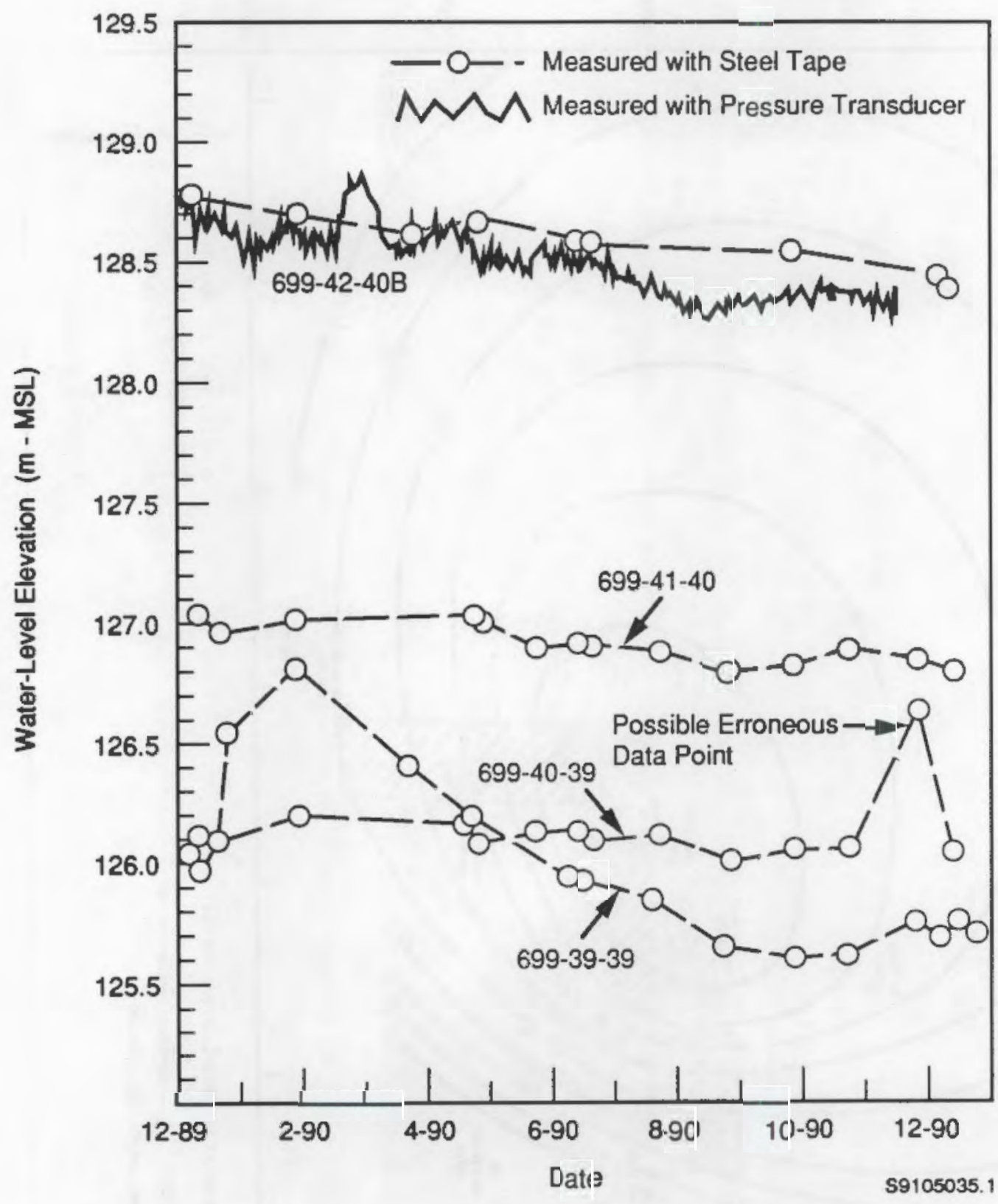

FIGURE 4. Hydrographs of Wells 699-39-39, 699-40-39, 699-41-40, and $699-42-40 B$

The water level in well 699-39-39 decreased $0.4 \mathrm{~m}(1.3 \mathrm{ft})$ between December 1989 and December 1990. However, the hydrograph of we11 699-39-39 in Figure 4 indicates that the water level in this well declined approximately 
$1.1 \mathrm{~m}(3.6 \mathrm{ft})$ between January 1990 and October 1990, after rising approximately $0.7 \mathrm{~m}(2.3 \mathrm{ft})$ between December 1989 and January 1990. The water level in this well has been changing significantly since 1987 . The hydrographs of wells 699-40-39, 699-41-40, and 699-42-40B, also shown in Figure 4, indicate that the water levels near well 699-39-39 were rélatively stable throughout the reporting period. The deviation between water levels measured in well 699-42-40B with the steel tape and those measured with the pressure transducer is negative drift attributed to instability of the pressure transducer.

Water-table maps of B Pond for November 1989 and December 1989 are presented in Smith and Gorst (1990) and Newcomer and McDonald (1990), respectively. Water-table maps of the Separations Areas for December 1989 and December 1990, which includes the B Pond area, are presented in Kasza (1990) and Kasza et al. (1990), respectively.

$\underline{U \text { Pond }}$

A map of the water table beneath the decommissioned $U$ Pond is presented in Figure 5. This map indicates that ground water flows radially, mostly to the north and east from an area near the 216-U-14 Ditch, located eastnortheast of the decommissioned $U$ Pond. This ditch continues to receive waste water (Brown et al. 1990). The Hanford Site water-table map in Plate 1 indicates that the ground-water mound in this area has influenced regional groundwater flow.

U Pond was decommissioned in 1984 and the elevation of the ground-water mound at that location continues to decline. The maximum elevation of the ground-water mound, which occurred in 1984, was approximately $148 \mathrm{~m}$ (485 ft) above mean sea level. The elevation of the ground-water mound beneath the decommissioned $U$ Pond, as reflected in the water level in well 299-W18-15, decreased as much as $4.97 \mathrm{~m}$ (16.34 ft) between June 1984 (RHO 1984) and June 1990. Between December 1989 and December 1990, the elevation of the groundwater mound decreased as much as $0.79 \mathrm{~m}(2.60 \mathrm{ft})$, as reflected in the water level in well 299-W19-1.

This decline in the elevation of the ground-water mound beneath the deactivated $U$ Pond has been observed in wells throughout the 200-West Area. 


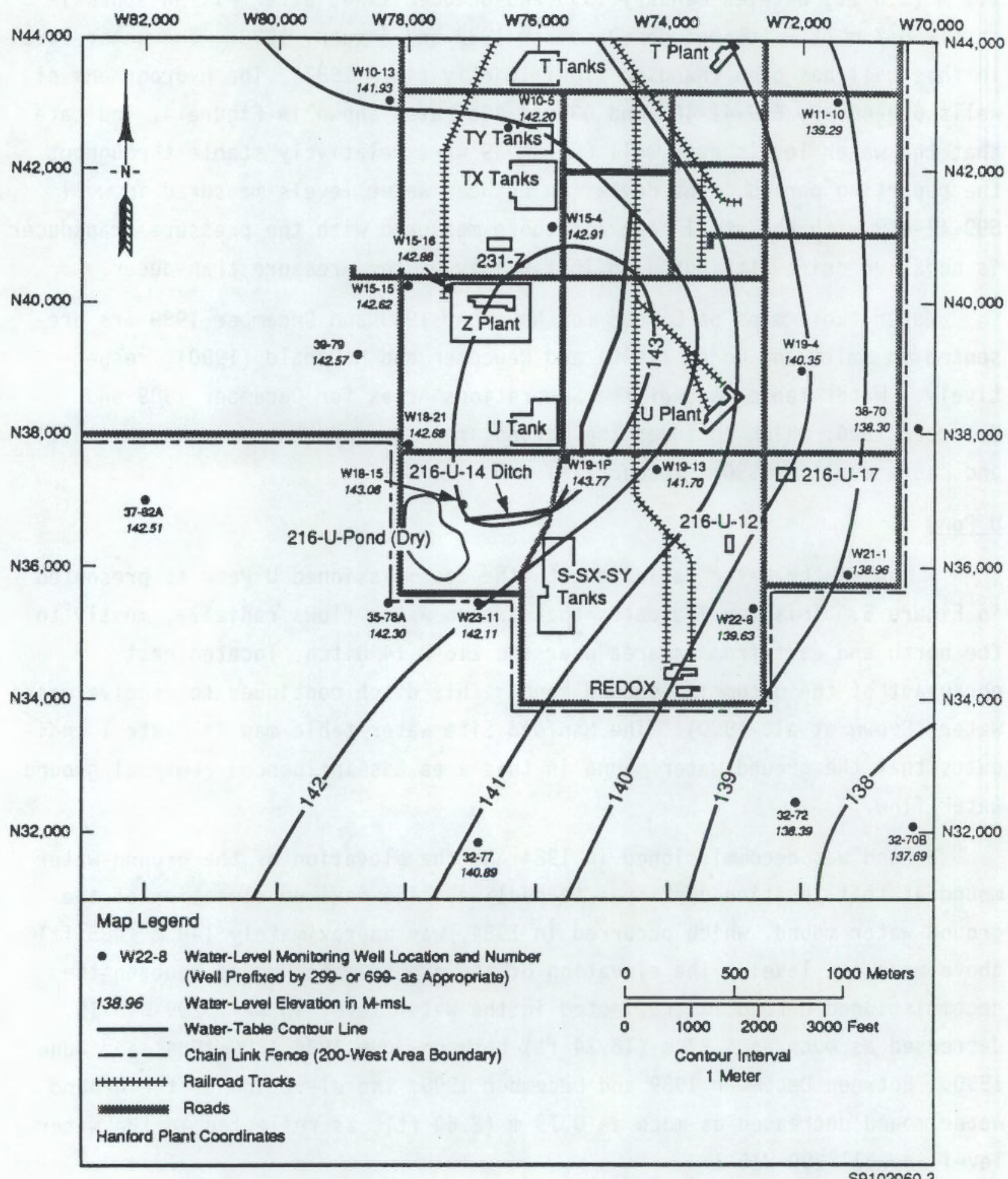

$\$ 9102060.3$

FIGURE 5. Water-Table Map of the Area Beneath the Decommissioned $U$ Pond in the 200-West Area for June 1990 
Hydrographs of wells 299-W18-21 and 299-W7-1, for which water levels declined during the reporting period, are presented in Figures 6 and 7 , respectiveiy. The locations of these wells are shown in Figure 5 and Plate 1 , respectively. A water-table map of the U Pond area for December 1989 is presented in Newcomer and McDonald '(1990).

Water-table maps of the Separations Areas for December 1989 and December 1990, which includes the deactivated U Pond area, are presented in Kasza (1990) and Kasza et al. (1990), respectively.

\section{0-N Area}

The Hanford Site water-table map indicates that ground water passing beneath the 100-N Area flows from the south through the gap between Gable Butte and Gable Mountain and discharges to the Columbia River. Ground-water elevations in the 100-N Area are primarily influenced by changes in stage elevation of the Columbia River and recharge from wastewater disposal facilities. A water-table map of the $100-\mathrm{N}$ Area for June 1990 is shown in Figure 8.

Hydrographs of we 11 s $199-\mathrm{N}-27$ and $199-\mathrm{N}-60$, located in the 100-N Area, and 699-81-58, located southeast of the 100-N Area, are shown in Figure 9. The 1ocations of wells $199-\mathrm{N}-27$ and $199-\mathrm{N}-60$ are shown in Figure 8 and well 699-81-58 in Plate 1. The hydrograph of well 199-N-27, located near the 1325-N liquid waste disposal facility, indicates that the water level declined approximately $1.4 \mathrm{~m}(4.6 \mathrm{ft})$ during the reporting period. The hydrograph of well 199-N-60, located near the 1324-N/NA liquid waste disposal facility, indicates that the water level declined approximately $1.9 \mathrm{~m}(6.2 \mathrm{ft})$ during the reporting period. The hydrograph of well 699-81-58, located southwest of the 100-N Area, indicates that the water level declined approximately $0.8 \mathrm{~m}$ $(2.6 \mathrm{ft})$ during the reporting period. These declines are primarily the result of decreasing wastewater discharging to the 1325-N and 1324-N/NA facilities. As expected, water levels in wells near the Columbia River increased between December 1989 and June 1990 and declined between June 1990 and December 1990, primarily as the result of the rise and fall of the river stage caused by spring runoff. Water-table maps of the 100-N Area for December 1989 are presented in the reports by Smith and Gorst (1990) and Newcomer and McDonald (1990). 


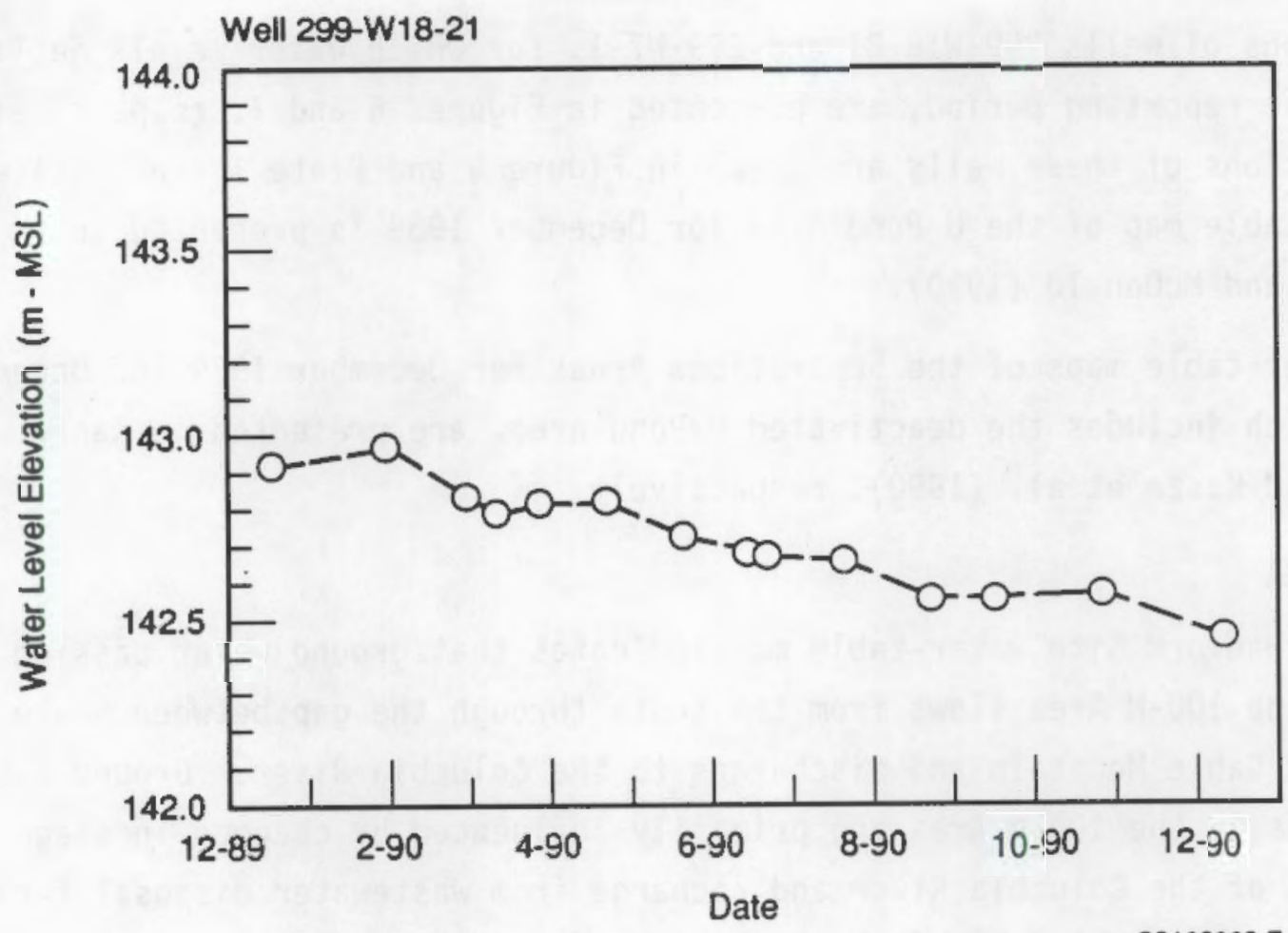

FIGURE 6. Hydrograph of Well 299-W18-21

Well 299-W7-1

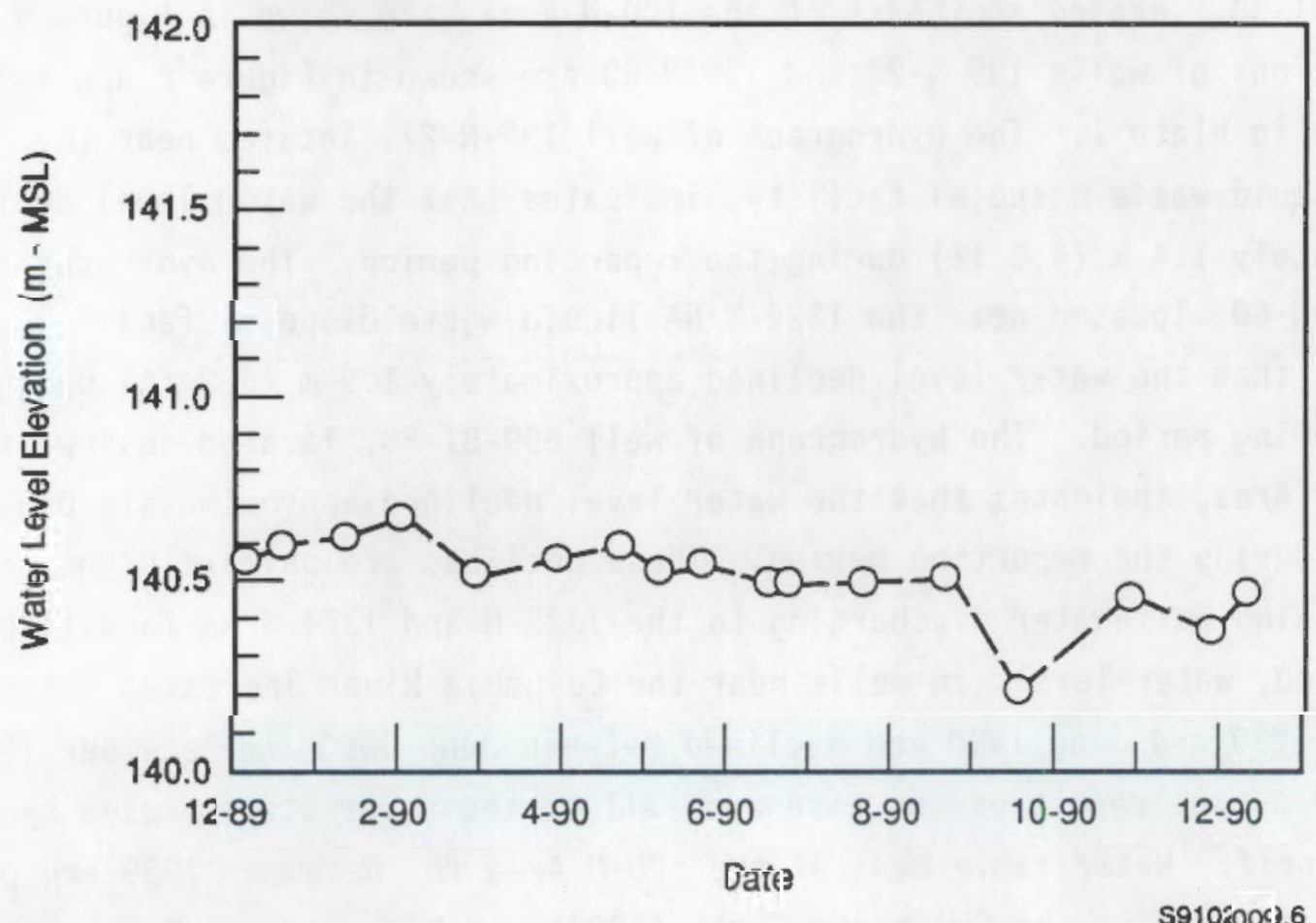

FIGURE 7. Hydrograph of Well 299-W7-1 


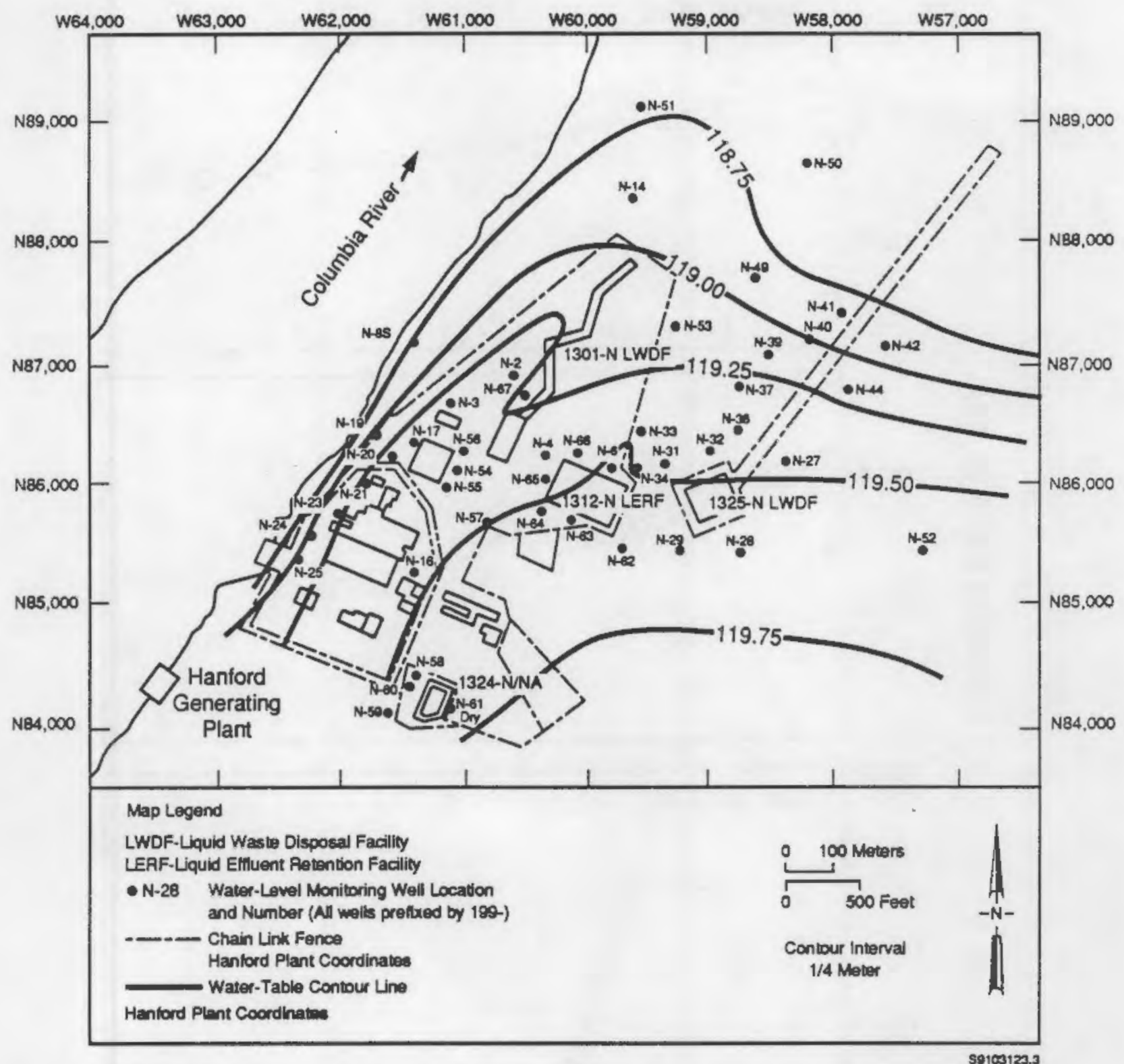

FIGURE 8. Water-Table Map Beneath the 1325-N Liquid Waste Disposal Facility in the $100-\mathrm{N}$ Area for June 1990

\section{Area}

A water-table map of the 300,1100 , and 3000 Areas for June 1990 is shown in Figure 10. The water-table contours indicate that ground water flows from the northwest, west, and southwest and discharges to the Columbia River in the vicinity of the 300 Area. The primary influences on the ground-water elevation are changes in the stage elevation of the Columbia River and recharge 

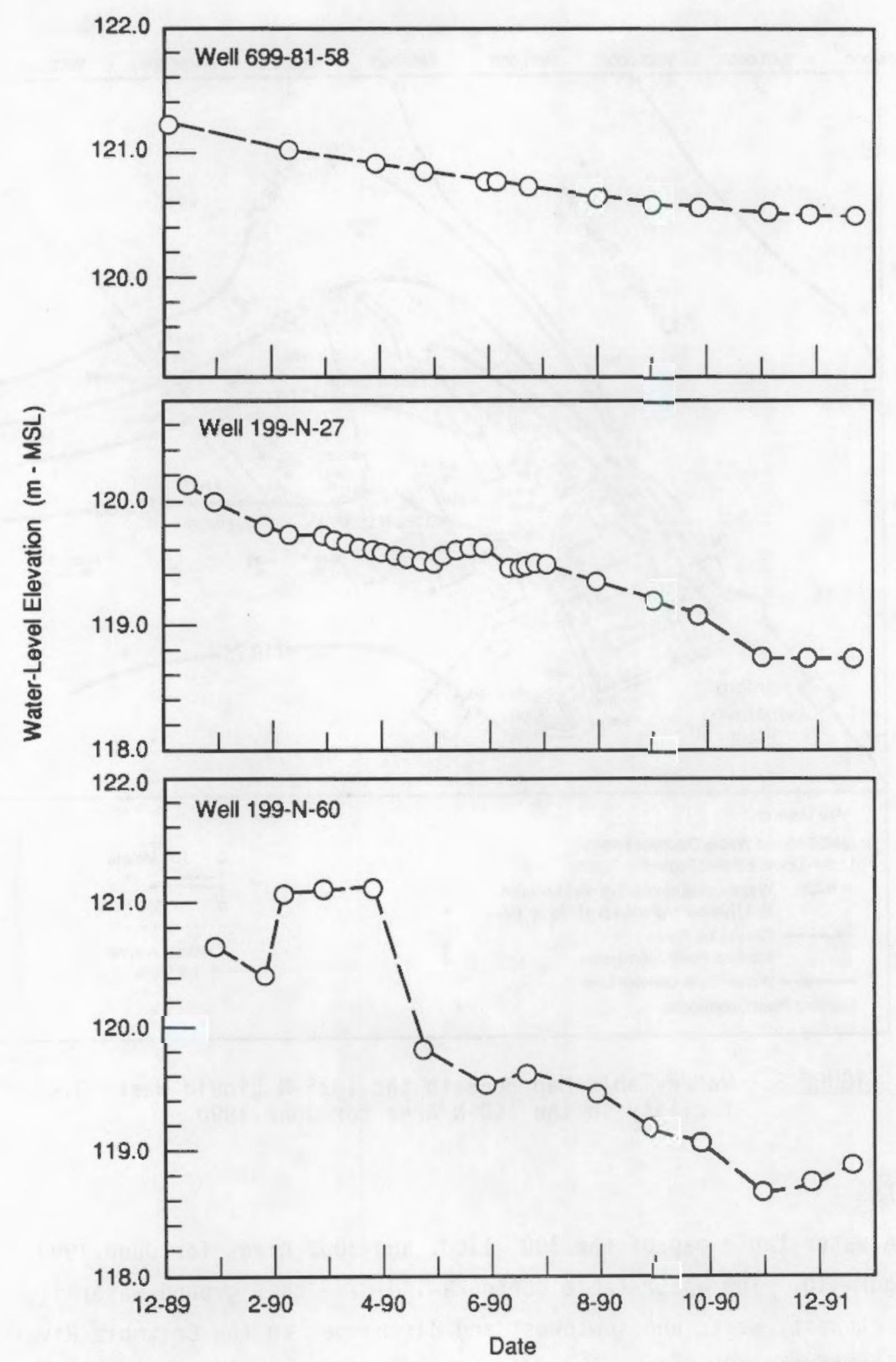

$\$ 9102009.5$

FIGURE 9. Hydrographs of Wel1s 699-81-58, 199-N-27, and 199-N-60

20 


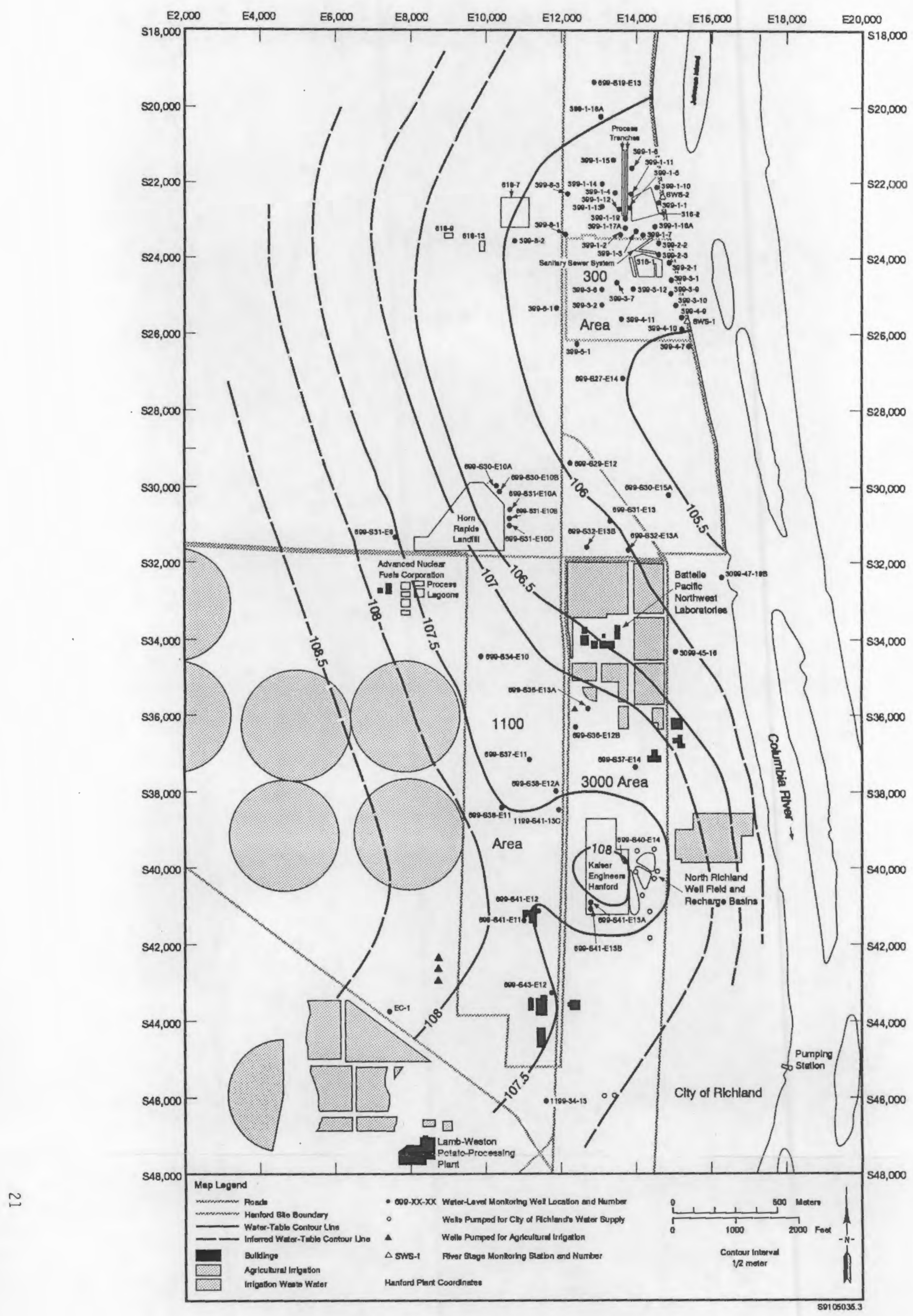

FIGURE 10. Water-Table Map Beneath the 300,1100 , and 3000 Areas for June 1990 

from the process trenches. These trenches have received large volumes of process water (Schalla et al. 1988). The configuration of the water table at any given time is dependent on these influences.

The water table rose approximately $1.3 \mathrm{~m} \cdot(4.3 \mathrm{ft})$ in most of the 300 Area between December 1989 and June 1990. This rise is primarily the result of the rise of the Columbia River stage. A hydrograph for well 399-8-1, shown in Figure 11, illustrates that the water-level response to the river stage occurred during June 1990. The hydrograph in Figure 11 also indicates that the water level in wel1 399-8-1 (Figure 10) responded to the rise of the Columbia River stage between October 1990 and December 1990. The Columbia River stage rose between November 1990 and December 1990 primarily because of meltwater runoff and storm runoff caused by an unseasonably warm storm event. Water-table maps of the 300 Area for December 1989 are presented in reports by Smith and Gorst (1990) and Newcomer and McDonald (1990).

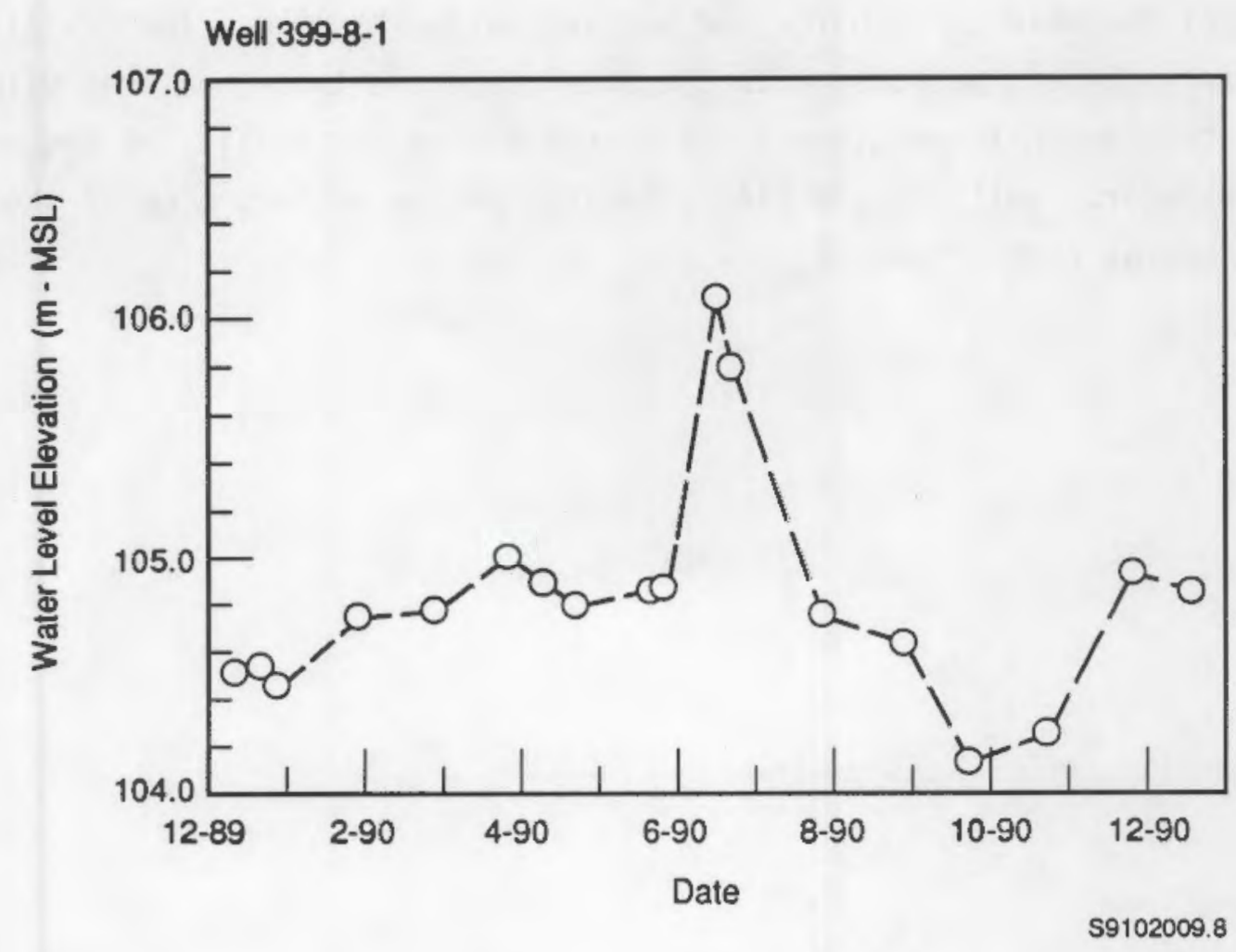

FIGURE 11. Hydrograph of Well 399-8-1 


\section{0 and 3000 Areas}

Ground water beneath the 1100 and 3000 Areas generally flows from west to east between the Yakima and Columbia rivers. The primary influence on the ground water beneath the 1100 Area is the North Richland well field and associated ground-water recharge basins. Water is pumped from the intake structure at the Columbia River and piped to a system of basins (ICF 1987), which recharges the unconfined aquifer. Water is then pumped from the aquifer via the well field for the city's water supply system. The unconfined aquifer is also influenced by changes in river stage, recharge from process lagoons at Advanced Nuclear Fuels Corporation, and by irrigation practices in the 3000 Area and west and southwest of the 1100 Area.

A water-table map of the 1100 and 3000 Areas, illustrated in Figure 10, indicates that a ground-water mound lies beneath the system of recharge basins. The ground-water mound developed as a result of recharge exceeding pumping. A hydrograph of well 699-S40-E14, presented in Figure 12, shows the water-level response to recharge and pumping during CY 1990 . The deviation between water levels measured with the steel tape and those measured with the pressure transducer is negative drift attributed to instability of the pressure transducer. Well 699-S40-E14 is located on the western edge of the recharge basins (see Figure 10). 


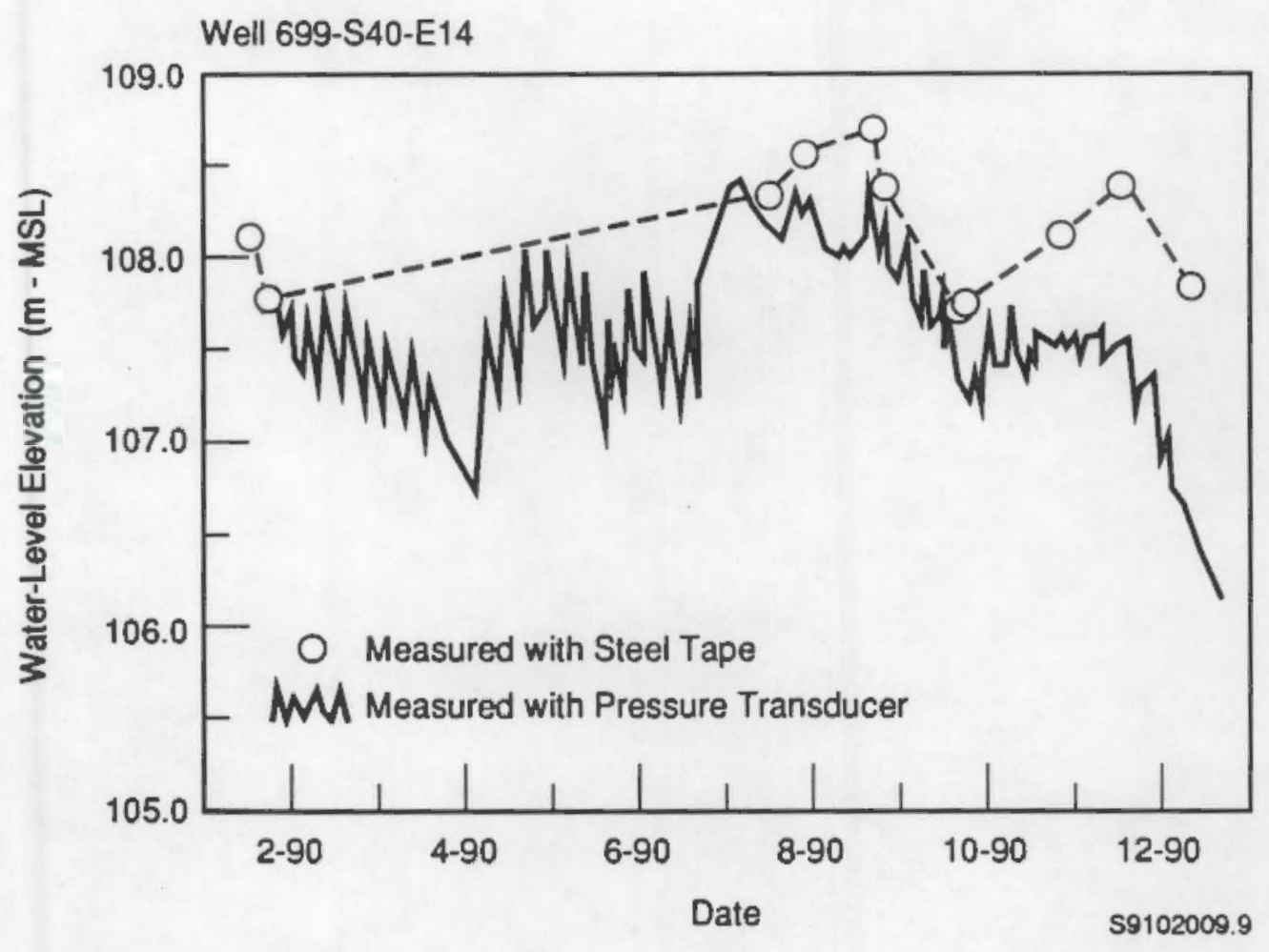

FIGURE 12. Hydrograph of Well 699-S40-E14 

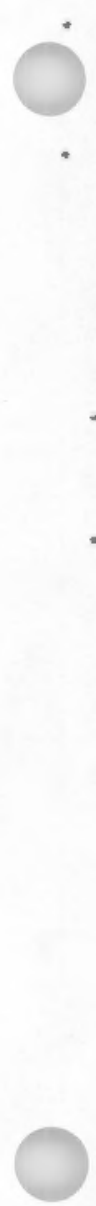

-

- .

. 


\section{SUMMARY AND CONCLUSIONS}

The elevation of the water table declined over most of the Hanford Site during 1990, particularly in the vicinity of production facilities in the 100 and 200 Areas. The water table responded to disequilibrium conditions caused by decreasing discharge to wastewater facilities. With the shutdown of Hanford production facilities, the water table is expected to continue to decline until new equilibrium conditions are established. Changes in the Hanford Site water table during 1990 are summarized as follows:

- The elevation of the ground-water mound beneath the decommissioned $U$ Pond declined as much as $0.8 \mathrm{~m}(2.6 \mathrm{ft})$ between December 1989 and December 1990, primarily as a result of continued dissipation of the ground-water mound beneath much of the 200-West Area.

- The elevation of the water table decreased as much as $1.9 \mathrm{~m}(6.2 \mathrm{ft})$ beneath the 100-N Area during the reporting period, primarily the result of decreasing discharge to wastewater facilities in the 100-N Area.

- The elevation of the ground-water mound beneath B Pond, which continues to receive wastewater, did not change significantly during the reporting period.

- The elevation of the water table beneath the 200-East Area decreased approximately $0.3 \mathrm{~m}$ ( $1 \mathrm{ft}$ ) during the reporting period, primarily in response to decreasing wastewater discharged to various ponds, cribs and trenches in the 200 Areas.

- The elevation of the water table in the 1100 and 3000 Areas fluctuated primarily in response to pumping and recharge at the north Richland well field and associated ground-water recharge basins during 1990.

- Significant changes in the elevation of the water table occurred near the Columbia River in June 1990 and again between November and December 1990. These were caused primarily by fluctuations in the river stage along the Hanford Reach between the area west of the 100-B and 100-C Areas and 300 Area. 

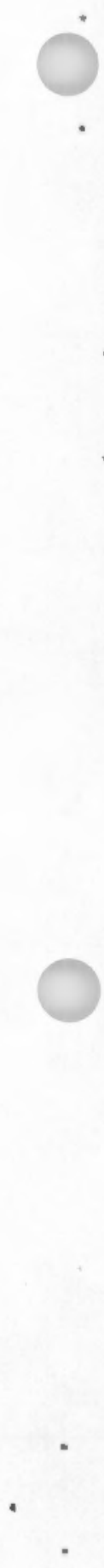


\section{REFERENCES}

ASTM. 1988. "Standard Method for Determining Subsurface Liquid Levels in a Borehole or Monitoring Well (Observation We11)." D 4750-87, American Society for Testing and Materials, Philadelphia, Pennsylvania.

Brown, M. J., R. K. P'Pool, and S. P. Thomas. 1990. Westinghouse Hanford Company Effluent Discharges and Solid Waste Management Report for Calendar Year 1989: 200/600 Areas. WHC-EP-0141-2, Westinghouse Hanford Company, Richland, Washington.

EPA. 1986. Resource Conservation and Recovery Act (RCRA) Ground-Water Monitoring Technical Enforcement Guidance Document. OWSER-9950.1, U.S. Environmental Protection Agency, Washington, D.C.

Fruland, R. M., and R. E. Lundgren, eds. 1989. RCRA Ground-Water Monitoring Projects for Hanford Facilities: Annual Progress Report for 1988. PNL-6852, Pacific Northwest Laboratory, Richland, Washington.

Garber, M. S., and F. C. Koopman. 1968. Methods of Measuring Water Levels in Deep Wells: U.S. Geological Survey TRWI, Book 8, Chap. A-1. U.S. Government Printing office, Washington, D.C.

Gephart, R. E., R. C. Arnett, R. G. Baca, L. S. Leonhart, and F. A. Spane, Jr. 1979. Hydrologic Studies Within the Columbia Plateau, Washington: An Integration of Current Knowledge. RHO-BWI-ST-5, Rockwell Hanford Operations, Richland, Washington.

Graham, M. J., M. D. Hall, S. R. Strait, and W. R. Brown. 1981. Hydrology of the Separations Area. RHO-ST-42, Rockwell Hanford Operations, Richland, Washington.

ICF. 1987. Hydrogeologic Study of North Richland Well Field and Groundwater Recharge Basins. Prepared by ICF Northwest for the City of Richland, Washington.

Jensen, E. J. 1987. Summary of Water-Level Measurements Around the 1325-N Crib During the Fall of 1985 and the Winter of 1986-1987. PNL-6374, Pacific Northwest Laboratory, Richland, Washington.

Kasza, G. L. 1990. Ground Water Maps of Hanford Site Separations Areas, December 1989. WHC-EP-0142-4, Westinghouse Hanford Company, Richland, Washington.

Kasza, G. L., S. F. Harris, and M. J. Hartman. 1990. Ground Water Maps of the Hanford Site. WHC-EP-0394-1, Westinghouse Hanford Company, Richland, Washington. 
Liikala, T. L., R. L. Aaberg, N. J. Aimo, D. J. Bates, T. J Gilmore, E. J. Jensen, G. V. Last, P. L. Oberlander, K. B. 01sen, K. R. Oster, L. R. Roome, J. C. Simpson, S. S. Teel, and E. J. Westergard. 1988. Geohydrologic Characterization of the Area Surrounding the 183-H Solar Evaporation Basins. PNL-6728, Pacific Northwest Laboratory, Richland, Washington.

Newcomer, D. R. 1990. Evaluation of Hanford Site Water-Table Changes - 1980 to 1990. PNL-7498, Pacific Northwest Laboratory, Richland, Washington.

Newcomer, D. R., and J. P. McDonald. 1990. Water-Table Elevations on the Hanford Site, December 1989. PNL-7374, Pacific Northwest Laboratory, Richland, Washington.

PNL. 1989. Procedures for Ground-Water Investigations. PNL-6894, Pacific Northwest Laboratory, Richland, Washington.

RHO. 1984. Unconfined Aquifer Water-Table Map - June 1984. H-2-38396, Rev. 17, Rockwell Hanford Operations, Richland, Washington.

Schalla, R., R. W. Wallace, R. L. Aaberg, S. P. Airhart, D. J. Bates, J. V. M. Carlile, C. S. Cline, D. I. Dennison, M. O. Freshley, P. R. Heller, E. J. Jensen, K. B. 01 sen, R. G. Parkhurst, J. T. Rieger, and E. J. Westergard. 1988. Interim Characterization Report for the 300 Area Process Trenches. PNL -6716 , Pacific Northwest Laboratory, Richland, Washington.

Smith, R. M., and W. R. Gorst. 1990. RCRA Ground-Water Monitoring Projects for Hanford Facilities: Annual Progress Report for 1989. PNL-7305, Pacific Northwest Laboratory, Richland, Washington.

USGS. 1977. National Handbook of Recommended Methods for Water Data Acquisition. U.S. Geological Survey, Office of Water Data Coordination, Reston, Virginia.

WHC. 1989. Environmental Investiqations and Site Characterization Manual. WHC-CM-7-7, vol. 1, Westinghouse Hanford Company, Richland, Washington.

Zimmerman, D. A., A. E. Reisenauer, G. D. Black, and M. A. Young. 1986. Hanford Site Water Table Changes 1950 Through 1980 - Data Observations and Evaluation. PNL-5506, prepared for Rockwell Hanford Operations by Pacific Northwest Laboratory, Richland, Washington. 


\section{APPENDIX A}

WATER-LEVEL MEASUREMENTS FOR THE HANFORD SITE, JUNE 1990 
APPENDIX A

WATER-LEVEL MEASUREMENTS FOR THE HANFORD SITE, JUNE 1990

TABLE A.1. Hanford Site Water-Level Measurements in Unconfined Aquifer Wells, June 1990 (Measured by PNL)

\begin{tabular}{|c|c|c|c|c|c|}
\hline Well & Date & $\begin{array}{c}\text { Casing } \\
\text { Elevation, (a) } \\
\mathrm{ft} \text { above MSL (a) } \\
\end{array}$ & $\begin{array}{l}\text { Depth to } \\
\text { Water, } \\
\text { ft } \\
\end{array}$ & $\begin{array}{l}\text { Water-Table } \\
\text { Elevation, } \\
\mathrm{ft} \text { above MSL } \\
\end{array}$ & $\begin{array}{l}\text { Water-Table } \\
\text { Elevation, } \\
\text { m above MSL }\end{array}$ \\
\hline $199-B 4-1$ & $06 / 18 / 90$ & 461.80 & 61.13 & 400.67 & 122.12 \\
\hline $199-D 2-5$ & $06 / 06 / 90$ & 460.87 & 73.73 & 387.14 & 118.00 \\
\hline $199-F 5-1$ & $06 / 07 / 90$ & 406.56 & 30.44 & 376.12 & 114.64 \\
\hline $199-\mathrm{H} 3-1$ & $06 / 07 / 90$ & 421.48 & 44.64 & 376.84 & 114.86 \\
\hline $199-K-11$ & $06 / 18 / 90$ & 467.66 & 70.98 & 396.68 & 120.91 \\
\hline $299-E 13-10$ & $06 / 19 / 90$ & 738.84 & 334.40 & 404.44 & 123.27 \\
\hline $299-\mathrm{E} 17-10$ & $06 / 15 / 90$ & 714.74 & 310.58 & 404.16 & 123.19 \\
\hline $299-E 18-1$ & $06 / 15 / 90$ & 720.24 & 315.80 & 404.44 & 123.27 \\
\hline $299-E 23-2(0)$ & $06 / 15 / 90$ & 720.64 & 316.66 & 403.98 & 123.13 \\
\hline $299-E 25-11$ & $06 / 14 / 90$ & 681.28 & 276.86 & 404.42 & 123.27 \\
\hline $299-E 25-32 P$ & $06 / 14 / 90$ & 670.04 & 264.34 & 405.70 & 123.66 \\
\hline $299-E 25-34$ & $06 / 14 / 90$ & 662.87 & 258.09 & 404.78 & 123.38 \\
\hline $299-E 25-35$ & $06 / 18 / 90$ & 674.39 & 270.04 & 404.35 & 123.25 \\
\hline $299-E 26-1$ & $06 / 18 / 90$ & 617.25 & 212.35 & 404.90 & 123.41 \\
\hline 299-E27-9 & $06 / 18 / 90$ & 629.21 & 224.96 & 404.25 & 123.22 \\
\hline 299-E28-1 & $06 / 18 / 90$ & 685.20 & 280.80 & 404.40 & 123.26 \\
\hline $299-E 28-27$ & & 680.37 & No Measu & rement & \\
\hline $299-E 32-2$ & $06 / 18 / 90$ & 670.06 & 266.28 & 403.78 & 123.07 \\
\hline $299-E 33-14$ & $06 / 18 / 90$ & 622.12 & 217.78 & 404.34 & 123.24 \\
\hline $299-E 33-33$ & $06 / 18 / 90$ & 640.18 & 236.12 & 404.06 & 123.16 \\
\hline $299-E 34-2$ & $06 / 18 / 90$ & 630.80 & 226.66 & 404.14 & 123.18 \\
\hline 299-E34-5 & $06 / 18 / 90$ & 590.79 & 185.76 & 405.03 & 123.45 \\
\hline 299-W7-1 & $06 / 19 / 90$ & 690.71 & 229.80 & 460.91 & 140.49 \\
\hline $299-W 7-4$ & $06 / 19 / 90$ & 671.69 & 209.32 & 462.37 & 140.93 \\
\hline $299-W 7-6$ & $06 / 19 / 90$ & 678.64 & 219.08 & 459.56 & 140.07 \\
\hline 299-W9-1 & $06 / 19 / 90$ & 737.73 & 273.51 & 464.22 & 141.49 \\
\hline 299-W10-5 & $06 / 19 / 90$ & 672.31 & 205.78 & 466.53 & 142.20 \\
\hline $299-W 10-13$ & $06 / 19 / 90$ & 699.04 & 233.38 & 465.66 & 141.93 \\
\hline $299-W 11-10$ & $06 / 19 / 90$ & 728.89 & 271.89 & 457.00 & 139.29 \\
\hline $299-W 15-16$ & $06 / 18 / 90$ & 684.89 & 216.14 & 468.75 & 142.88 \\
\hline $299-W 18-15$ & $06 / 18 / 90$ & 660.76 & 191.39 & 469.37 & 143.06 \\
\hline $299-W 18-21$ & $06 / 18 / 90$ & 668.62 & 200.52 & 468.10 & 142.68 \\
\hline $299-W 18-24$ & $06 / 18 / 90$ & 684.35 & 215.14 & 469.21 & 143.02 \\
\hline 299-W19-1P & $06 / 18 / 90$ & 674.06 & 202.37 & 471.69 & 143.77 \\
\hline 299-W19-4 & $06 / 18 / 90$ & 715.26 & 254.78 & 460.48 & 140.35 \\
\hline $299-W 19-13$ & $06 / 18 / 90$ & 695.08 & 230.17 & 464.91 & 141.70 \\
\hline 299-W21-1 & $06 / 18 / 90$ & 699.26 & 243.37 & 455.89 & 138.96 \\
\hline
\end{tabular}


IABLE A.1. (contd)

\begin{tabular}{|c|c|c|c|c|c|}
\hline $\mathrm{Hell}$ & Date & $\begin{array}{r}\text { Elevation, } \\
\mathrm{ft} \text { above } \mathrm{MSL}(\mathrm{a}) \\
\end{array}$ & $\begin{array}{c}\text { Water, } \\
\mathrm{ft}\end{array}$ & $\begin{array}{c}\text { Elevation, } \\
\mathrm{ft} \text { above MSL }\end{array}$ & $\begin{array}{l}\text { Elevation, } \\
\text { m above MSI }\end{array}$ \\
\hline 299-W22-8 & $06 / 18 / 90$ & 683.55 & 225.44 & 458.11 & 139.63 \\
\hline 299-W23-11 & $06 / 13 / 90$ & 664.14 & 197.89 & 466.25 & 142.11 \\
\hline $399-8-1$ & $06 / 19 / 90$ & 394.88 & 46.79 & 348.09 & 106.10 \\
\hline $699-2-3$ & $06 / 18 / 90$ & 477.14 & 86.46 & 390.68 & 119.08 \\
\hline $699-2-33 A$ & $06 / 19 / 90$ & 536.37 & 132.53 & 403.84 & 123.09 \\
\hline $699-3-45$ & $06 / 15 / 90$ & 504.54 & 92.80 & 411.74 & 125.50 \\
\hline $699-8-17$ & $06 / 18 / 90$ & 522.44 & 123.46 & 398.98 & 121.61 \\
\hline $699-8-25$ & $06 / 19 / 90$ & 509.30 & 108.91 & 400.39 & 122.04 \\
\hline $699-8-32$ & $06 / 19 / 90$ & 554.39 & 153.58 & 400.81 & 122.17 \\
\hline $699-9-E 2$ & $06 / 18 / 90$ & 418.09 & 46.00 & 372.09 & 113.41 \\
\hline $699-10-54 B$ & $06 / 13 / 90$ & 516.20 & 103.28 & 412.92 & 125.86 \\
\hline $699-10-E 12$ & $06 / 18 / 90$ & 430.86 & 73.42 & 357.44 & 108.95 \\
\hline $699-11-45 A$ & $06 / 13 / 90$ & 578.58 & 167.04 & 411.54 & 125.44 \\
\hline $699-14-38$ & $06 / 13 / 90$ & 514.89 & 110.29 & 404.60 & 123.32 \\
\hline $699-14-47$ & $06 / 13 / 90$ & 587.23 & 175.43 & 411.80 & 125.52 \\
\hline $699-15-15 A$ & $06 / 18 / 90$ & 547.14 & 147.99 & 399.15 & 121.66 \\
\hline $699-15-26$ & $06 / 14 / 90$ & 523.83 & 121.97 & 401.86 & 122.49 \\
\hline $699-17-5$ & $06 / 18 / 90$ & 433.19 & 44.59 & 388.60 & 118.45 \\
\hline $699-17-70$ & $06 / 15 / 90$ & 563.18 & 88.81 & 474.37 & 144.59 \\
\hline $699-19-43$ & $06 / 13 / 90$ & 551.58 & 146.80 & 404.78 & 123.38 \\
\hline $699-19-58$ & $06 / 13 / 90$ & 573.05 & 154.02 & 419.03 & 127.72 \\
\hline $699-19-88$ & $06 / 15 / 90$ & 644.45 & 131.11 & 513.34 & 156.47 \\
\hline $699-20-20$ & $06 / 14 / 90$ & 505.58 & 103.62 & 401.96 & 122.52 \\
\hline $699-20-39$ & $06 / 13 / 90$ & 539.98 & 136.11 & 403.87 & 123.10 \\
\hline $699-20-E 12$ & $06 / 18 / 90$ & 437.25 & 79.49 & 357.76 & 109.05 \\
\hline $699-21-17$ & $06 / 18 / 90$ & 527.31 & 129.28 & 398.03 & 121.32 \\
\hline $699-24-1 T$ & $06 / 18 / 90$ & 475.54 & 98.89 & 376.65 & 114.80 \\
\hline $699-24-33$ & $06 / 13 / 90$ & 524.21 & 120.74 & 403.47 & 122.98 \\
\hline $699-25-55$ & $06 / 19 / 90$ & 676.55 & 263.13 & 413.42 & 126.01 \\
\hline $699-25-70$ & $06 / 13 / 90$ & 629.78 & 181.18 & 448.60 & 136.73 \\
\hline $699-26-15 \mathrm{~A}$ & $06 / 18 / 90$ & 442.64 & 43.55 & 399.09 & 121.64 \\
\hline $699-26-89$ & $06 / 15 / 90$ & 653.08 & 179.95 & 473.13 & 144.21 \\
\hline $699-27-8$ & $06 / 18 / 90$ & 465.67 & 70.86 & 394.81 & 120.34 \\
\hline $699-28-40$ & $06 / 14 / 90$ & 559.44 & 155.47 & 403.97 & 123.13 \\
\hline $699-28-52 A$ & $06 / 19 / 90$ & 684.67 & 279.23 & 405.44 & 123.58 \\
\hline $699-29-78$ & $06 / 13 / 90$ & 647.05 & 183.33 & 463.72 & 141.34 \\
\hline $699-31-31$ & $06 / 14 / 90$ & 529.32 & 125.84 & 403.48 & 122.98 \\
\hline $699-32-22$ & $06 / 14 / 90$ & 517.55 & 116.00 & 401.55 & 122.39 \\
\hline $699-32-43$ & $06 / 14 / 90$ & 516.62 & 112.48 & 404.14 & 123.18 \\
\hline $699-32-62$ & $06 / 15 / 90$ & 707.09 & 277.90 & 429.19 & 130.82 \\
\hline $699-32-70 B$ & $06 / 13 / 90$ & 666.68 & 214.94 & 451.74 & 137.69 \\
\hline $699-32-72$ & $06 / 13 / 90$ & 668.16 & 214.13 & 454.03 & 138.39 \\
\hline $699-32-77$ & $06 / 13 / 90$ & 653.74 & 191.50 & 462.24 & 140.89 \\
\hline $699-33-56$ & $06 / 19 / 90$ & .03 & 311.94 & 405.09 & 123.47 \\
\hline $699-34-39 A$ & $06 / 14 / 90$ & 537.07 & 133.04 & 404.03 & 123.15 \\
\hline
\end{tabular}

Casing Depth to Water-Table Water-Table 


\section{TABLE A.1. (contd)}

\begin{tabular}{|c|c|c|c|c|c|}
\hline We11 & Date & $\begin{array}{l}\text { Elevation, } \\
\mathrm{ft} \text { above MSL }(\mathrm{a})\end{array}$ & $\begin{array}{c}\text { Water, } \\
\mathrm{ft}\end{array}$ & $\begin{array}{c}\text { Elevation, } \\
\mathrm{ft} \text { above MSL }\end{array}$ & $\begin{array}{l}\text { Elevation, } \\
\text { m above MSL }\end{array}$ \\
\hline $699-34-41 B$ & $06 / 14 / 90$ & 570.89 & 166.69 & 404.20 & 123.20 \\
\hline $699-34-42$ & $06 / 14 / 90$ & 540.20 & 135.97 & 404.23 & 123.21 \\
\hline $699-34-51$ & $06 / 19 / 90$ & 736.76 & 332.22 & 404.54 & 123.30 \\
\hline $699-34-88$ & $06 / 13 / 90$ & 632.82 & 163.10 & 469.72 & 143,17 \\
\hline $699-35-9$ & $06 / 18 / 90$ & 499.83 & 113.19 & 386.64 & 117.85 \\
\hline $699-35-66$ & $06 / 15 / 90$ & 725.65 & 285.99 & 439.66 & 134.01 \\
\hline $699-35-70$ & $06 / 15 / 90$ & 693.72 & 241.74 & 451.98 & 137.76 \\
\hline $699-35-78 A$ & $06 / 13 / 90$ & 660.65 & 193.79 & 466.86 & 142.30 \\
\hline $699-36-61 A$ & $06 / 15 / 90$ & 748.11 & 339.22 & 408.89 & 124.63 \\
\hline $699-36-93$ & $06 / 15 / 90$ & 644.77 & 172.42 & 472.35 & 143.97 \\
\hline $699-37-43$ & $06 / 14 / 90$ & 690.17 & 285.20 & 404.97 & 123.43 \\
\hline $699-37-82 A$ & $06 / 13 / 90$ & 636.75 & 169.21 & 467.54 & 142.51 \\
\hline $699-38-65$ & $06 / 15 / 90$ & 753.33 & 322.81 & 430.52 & 131.22 \\
\hline $699-38-70$ & $06 / 15 / 90$ & 710.67 & 256.93 & 453.74 & 138.30 \\
\hline $699-39-39$ & $06 / 14 / 90$ & 536.65 & 123.54 & 413.11 & 125.92 \\
\hline $699-39-79$ & $06 / 19 / 90$ & 673.52 & 205.76 & 467.76 & 142.57 \\
\hline $699-40-1$ & $06 / 18 / 90$ & 438.71 & 74.31 & 364.40 & 111.07 \\
\hline $699-40-33 A$ & $06 / 14 / 90$ & 518.05 & 106.73 & 411.32 & 125.37 \\
\hline $699-40-62$ & $06 / 15 / 90$ & 747.78 & 340.92 & 406.86 & 124.01 \\
\hline $699-41-23$ & $06 / 11 / 90$ & 466.50 & 67.85 & 398.65 & 121.51 \\
\hline $699-42-12 A$ & $06 / 18 / 90$ & 514.27 & 137.73 & 376.54 & 114.77 \\
\hline $699-42-40 B$ & $06 / 14 / 90$ & 546.46 & 124.35 & 422.11 & 128.66 \\
\hline $699-43-42$ & $06 / 14 / 90$ & 566.36 & 145.36 & 421.00 & 128.32 \\
\hline $699-43-89$ & $06 / 13 / 90$ & 644.15 & 177.46 & 466.69 & 142.25 \\
\hline $699-43-104$ & $06 / 15 / 90$ & 766.07 & 265.48 & 500.59 & 152.58 \\
\hline $699-44-64$ & $06 / 15 / 90$ & 725.60 & 317.94 & 407.66 & 124.25 \\
\hline $699-45-42$ & $06 / 11 / 90$ & 577.33 & 159.74 & 417.59 & 127.28 \\
\hline $699-45-69 A$ & $06 / 15 / 90$ & 725.46 & 276.76 & 448.70 & 136.76 \\
\hline $699-46-21 B$ & $06 / 11 / 90$ & 522.02 & 130.36 & 391.66 & 119.38 \\
\hline $699-47-35 A$ & $06 / 11 / 90$ & 476.36 & 62.17 & 414.19 & 126.25 \\
\hline $699-47-46 A$ & $06 / 11 / 90$ & 580.14 & 174.74 & 405.40 & 123.57 \\
\hline $699-47-60$ & $06 / 14 / 90$ & 649.84 & 245.99 & 403.85 & 123.09 \\
\hline $699-48-7$ & $06 / 18 / 90$ & 384.72 & 20.02 & 364.70 & 111.16 \\
\hline $699-48-71$ & $06 / 15 / 90$ & 688.15 & 241.37 & 446.78 & 136.18 \\
\hline $699-49-13 E$ & $06 / 18 / 90$ & 412.72 & 49.75 & 362.97 & 110.63 \\
\hline$-49-28$ & $06 / 11 / 90$ & 535.40 & 140.93 & 394.47 & 120.23 \\
\hline $49-79$ & $06 / 13 / 90$ & 689.20 & 231.90 & 457.30 & 139.39 \\
\hline $50-30$ & $06 / 11 / 90$ & 528.84 & 134.38 & 394.46 & 120.23 \\
\hline $50-42$ & $06 / 11 / 90$ & 466.84 & 55.23 & 411.61 & 125.46 \\
\hline $50-53$ & $06 / 11 / 90$ & 556.30 & 152.36 & 403.94 & 123.12 \\
\hline $50-85$ & $06 / 04 / 90$ & 739.35 & 283.41 & 455.94 & 138.97 \\
\hline $51-63$ & $06 / 11 / 90$ & 571.84 & 165.80 & 406.04 & 123.76 \\
\hline $51-75$ & $06 / 11 / 90$ & 641.51 & 191.24 & 450.27 & 137.24 \\
\hline $52-19$ & $06 / 11 / 90$ & 411.08 & 48.80 & 362.28 & 110.42 \\
\hline 00 & $06 / 11 / 90$ & 530.99 & 132.63 & 398.36 & 121.42 \\
\hline 48B & $06 / 11 / 90$ & 442.71 & 38.21 & 404.50 & 123.29 \\
\hline
\end{tabular}


TABLE A.1. (contd)

\begin{tabular}{|c|c|c|c|c|c|}
\hline Well & Date & $\begin{array}{l}\text { Elevation, } \\
\mathrm{ft} \text { above MSL }(\mathrm{a}) \\
\end{array}$ & $\begin{array}{c}\text { Water, } \\
\mathrm{ft}\end{array}$ & $\begin{array}{l}\text { Elevation, } \\
\mathrm{ft} \text { above MSL }\end{array}$ & $\begin{array}{l}\text { Elevation, } \\
\text { m above MS }\end{array}$ \\
\hline $699-53-55 C$ & $06 / 08 / 90$ & 576.08 & 172.79 & 403.29 & 122.92 \\
\hline $699-54-19$ & $06 / 11 / 90$ & 383.60 & 21.23 & 362.37 & 110.45 \\
\hline $699-54-34$ & $06 / 11 / 90$ & 550.24 & 140.80 & 409.44 & 124.80 \\
\hline $699-54-37 A$ & $06 / 11 / 90$ & 534.17 & 124.76 & 409.41 & 124.79 \\
\hline $699-54-42$ & $06 / 11 / 90$ & 511.49 & 115.38 & 396.11 & 120.73 \\
\hline $699-54-45 A$ & $06 / 11 / 90$ & 494.29 & 96.55 & 397.74 & 121.23 \\
\hline $699-54-48$ & $06 / 11 / 90$ & 457.02 & 53.80 & 403.22 & 122.90 \\
\hline $699-55-21$ & $06 / 11 / 90$ & 395.96 & 34.82 & 361.14 & 110.08 \\
\hline $699-55-40$ & $06 / 11 / 90$ & 543.13 & 133.10 & 410.03 & 124.98 \\
\hline $699-55-44$ & $06 / 11 / 90$ & 519.67 & 124.28 & 395.39 & 120.51 \\
\hline $699-55-50 C$ & $06 / 11 / 90$ & 444.43 & 41.22 & 403.21 & 122.90 \\
\hline $699-55-70$ & $06 / 11 / 90$ & 569.03 & 136.33 & 432.70 & 131.89 \\
\hline $699-55-76$ & $06 / 13 / 90$ & 583.24 & 138.66 & 444.58 & 135.51 \\
\hline $699-55-89$ & $06 / 04 / 90$ & 617.43 & 162.79 & 454.64 & 138.57 \\
\hline $699-55-95$ & $06 / 04 / 90$ & 777.05 & 311.16 & 465.89 & 142.00 \\
\hline $699-56-43$ & $06 / 11 / 90$ & 540.42 & 131.05 & 409.37 & 124.78 \\
\hline $699-57-25 A$ & $06 / 07 / 90$ & 414.57 & 49.98 & 364.59 & 111.13 \\
\hline $699-57-29 B$ & $06 / 07 / 90$ & 416.18 & 53.83 & 362.35 & 110.44 \\
\hline $699-57-83 A$ & $06 / 04 / 90$ & 577.96 & 145.05 & 432.91 & 131.95 \\
\hline $699-58-24$ & $06 / 07 / 90$ & 418.80 & 56.54 & 362.26 & 110.42 \\
\hline $699-59-32$ & $06 / 07 / 90$ & 424.29 & 61.68 & 362.61 & 110.52 \\
\hline $699-59-58$ & $06 / 08 / 90$ & 497.77 & 95.39 & 402.38 & 122.65 \\
\hline $699-59-80 B$ & $06 / 13 / 90$ & 583.25 & 154.43 & 428.82 & 130.70 \\
\hline $699-60-32$ & $06 / 07 / 90$ & 425.30 & 62.87 & 362.43 & 110.47 \\
\hline $699-60-60$ & $06 / 06 / 90$ & 512.03 & 108.94 & 403.09 & 122.86 \\
\hline $699-61-37$ & $06 / 07 / 90$ & 442.94 & 60.88 & 382.06 & 116.45 \\
\hline $699-61-41$ & $06 / 07 / 90$ & 428.92 & 32.62 & 396.30 & 120.79 \\
\hline $699-61-62$ & $06 / 06 / 90$ & 497.51 & 94.47 & 403.04 & 122.85 \\
\hline $699-61-66$ & $06 / 06 / 90$ & 522.18 & 119.93 & 402.25 & 122.61 \\
\hline $699-62-31$ & $06 / 07 / 90$ & 434.12 & 71.74 & 362.38 & 110.45 \\
\hline $699-62-43 A$ & $06 / 07 / 90$ & 432.30 & 35.67 & 396.63 & 120.89 \\
\hline $699-63-25 A$ & $06 / 07 / 90$ & 395.15 & 32.96 & 362.19 & 110.40 \\
\hline $699-63-51$ & $06 / 07 / 90$ & 424.54 & 24.08 & 400.46 & 122.06 \\
\hline $699-63-58$ & $06 / 08 / 90$ & 491.90 & 90.06 & 401.84 & 122.48 \\
\hline $63-90$ & $06 / 04 / 90$ & 509.73 & 109.39 & 400.34 & 122.02 \\
\hline $64-27$ & $06 / 07 / 90$ & 414.29 & 52.00 & 362.29 & 110.43 \\
\hline $54-62$ & $06 / 06 / 90$ & 500.25 & 98.58 & 401.67 & 122.43 \\
\hline $65-50$ & $06 / 07 / 90$ & 467.06 & 66.59 & 400.47 & 122.06 \\
\hline $65-59 A$ & $06 / 08 / 90$ & 506.96 & 105.43 & 401.53 & 122.39 \\
\hline $699-65-72$ & $06 / 06 / 90$ & 540.28 & 139.97 & 400.31 & 122.01 \\
\hline $699-65-83$ & $06 / 06 / 90$ & 485.63 & 85.78 & 399.85 & 121.87 \\
\hline $699-65-95$ & $06 / 06 / 90$ & 452.26 & 50.38 & 401.88 & 122.49 \\
\hline $699-66-23$ & $06 / 07 / 90$ & 389.01 & 24.00 & 365.01 & 111.26 \\
\hline $699-66-38$ & $06 / 07 / 90$ & 436.24 & 33.44 & 402.80 & 122.77 \\
\hline $699-66-39$ & $06 / 07 / 90$ & 453.78 & 47.03 & 406.75 & 123.98 \\
\hline $699-66-58$ & $06 / 08 / 90$ & 503.33 & 101.96 & 401.37 & 122.34 \\
\hline
\end{tabular}




\begin{tabular}{|c|c|}
\hline Well & Date \\
\hline $699-66-64$ & $06 / 06 / 90$ \\
\hline $699-66-91$ & $06 / 06 / 90$ \\
\hline $699-66-103$ & $06 / 04 / 90$ \\
\hline $699-67-51$ & $06 / 07 / 90$ \\
\hline $699-67-86$ & $06 / 06 / 90$ \\
\hline $699-67-98$ & $06 / 06 / 90$ \\
\hline $699-68-105$ & $06 / 04 / 90$ \\
\hline $699-69-38$ & $06 / 07 / 90$ \\
\hline $699-69-45(0)$ & $06 / 07 / 90$ \\
\hline $699-70-23$ & $06 / 07 / 90$ \\
\hline $699-70-68$ & $06 / 06 / 90$ \\
\hline $699-71-30$ & $06 / 07 / 90$ \\
\hline $699-71-52$ & $06 / 07 / 90$ \\
\hline $699-71-77$ & $06 / 06 / 90$ \\
\hline $72-73$ & $06 / 06 / 90$ \\
\hline 88 & $06 / 06 / 90$ \\
\hline-92 & $06 / 06 / 90$ \\
\hline-61 & $06 / 06 / 90$ \\
\hline $74-44$ & $06 / 07 / 90$ \\
\hline$-74-48$ & $06 / 07 / 90$ \\
\hline$-77-36$ & $06 / 07 / 90$ \\
\hline $7-54$ & $06 / 06 / 90$ \\
\hline 69 & $06 / 06 / 90$ \\
\hline 69 & $06 / 07 / 90$ \\
\hline 695 & $06 / 06 / 90$ \\
\hline $32-45 A$ & $06 / 06 / 90$ \\
\hline $699-83-47$ & $06 / 06 / 90$ \\
\hline $699-86-42$ & $06 / 06 / 90$ \\
\hline $699-87-55$ & $06 / 06 / 90$ \\
\hline $699-89-35$ & $06 / 07 / 90$ \\
\hline $699-90-45$ & $06 / 07 / 90$ \\
\hline $699-91-37$ & $06 / 07 / 90$ \\
\hline $699-92-49$ & $06 / 06 / 90$ \\
\hline $699-96-49$ & $06 / 06 / 90$ \\
\hline $699-97-43$ & $06 / 07 / 90$ \\
\hline 699 & $06 / 19 / 90$ \\
\hline 699 & $06 / 18 / 90$ \\
\hline 699 & $06 / 18 / 90$ \\
\hline 699 & $06 / 18 / 90$ \\
\hline 699 & $06 / 15 / 90$ \\
\hline 699 & $06 / 18 / 90$ \\
\hline $699-$ & $06 / 20 / 90$ \\
\hline $699-\$ 12-29$ & $06 / 15 / 90$ \\
\hline $699-S 14-20 A$ & $06 / 19 / 90$ \\
\hline $699-S 18-E 2 A$ & $06 / 20 / 90$ \\
\hline $699-519-11$ & $06 / 20 / 90$ \\
\hline
\end{tabular}

\section{TABLE A.1. (contd)}

\begin{tabular}{|c|c|c|c|}
\hline $\begin{array}{c}\text { Casing } \\
\text { Elevation, } \\
\mathrm{ft} \text { above MSL (a) } \\
\end{array}$ & $\begin{array}{l}\text { Depth to } \\
\text { Water, } \\
\mathrm{ft} \\
\end{array}$ & $\begin{array}{l}\text { Water-Table } \\
\text { Elevation, } \\
\mathrm{ft} \text { above MSL } \\
\end{array}$ & $\begin{array}{l}\text { Water-Table } \\
\text { Elevation, } \\
\text { m above MSL }\end{array}$ \\
\hline 505.92 & 104.78 & 401.14 & 122.27 \\
\hline 467.75 & 66.27 & 401.48 & 122.37 \\
\hline 463.01 & 61.08 & 401.93 & 122.51 \\
\hline 524.59 & 124.00 & 400.59 & 122.10 \\
\hline 472.39 & 72.57 & 399.82 & 121.87 \\
\hline 455.47 & 52.96 & 402.51 & 122.69 \\
\hline 451.85 & 51.56 & 400.29 & 122.01 \\
\hline 422.95 & 21.80 & 401.15 & 122.27 \\
\hline 486.94 & B7. 35 & 399.59 & 121.80 \\
\hline 391.71 & 24.66 & 367.05 & 111.88 \\
\hline 526.21 & 125.81 & 400.40 & 122.04 \\
\hline 400.68 & 30.20 & 370.48 & 112.92 \\
\hline 523.04 & 123.12 & 399.92 & 121.90 \\
\hline 472.28 & 73.24 & 399.04 & 121.63 \\
\hline 482.57 & 83.72 & 398.85 & 121.57 \\
\hline 437.37 & 34.28 & 403.09 & 122.86 \\
\hline 452.22 & 49.48 & 402.74 & 122.76 \\
\hline 531.53 & 131.58 & 399.95 & 121.90 \\
\hline 445.18 & 48.26 & 396.92 & 120.98 \\
\hline 487.18 & 88.42 & 398.76 & 121.54 \\
\hline 412.28 & 36.14 & 376.14 & 114.65 \\
\hline 480.59 & 82.49 & 398.10 & 121.34 \\
\hline 469.88 & 73.72 & 396.16 & 120.75 \\
\hline 406.47 & 27.17 & 379.30 & 115.61 \\
\hline 439.55 & 43.18 & 396.37 & 120.81 \\
\hline 413.73 & 24.60 & 389.13 & 118.61 \\
\hline 435.27 & 46.11 & 389.16 & 118.62 \\
\hline 409.92 & 25.21 & 384.71 & 117.26 \\
\hline 458.63 & 70.03 & 388.60 & 118.45 \\
\hline 397.46 & 22.11 & 375.35 & 114.41 \\
\hline 422.15 & 37.43 & 384.72 & 117.26 \\
\hline 422.93 & 47.92 & 375.01 & 114.30 \\
\hline 432.00 & 48.12 & 383.88 & 117.01 \\
\hline 419.29 & 36.33 & 382.96 & 116.73 \\
\hline 421.81 & 42.43 & 379.38 & 115.64 \\
\hline 523.50 & 123.76 & 399.74 & 121.84 \\
\hline 397.90 & 43.48 & 354.42 & 108.03 \\
\hline 430.47 & 57.99 & 372.48 & 113.53 \\
\hline 378.29 & 27.33 & 350.96 & 106.97 \\
\hline 527.12 & 119.19 & 407.93 & 124.34 \\
\hline 503.81 & 106.89 & 396.92 & 120.98 \\
\hline 435.52 & 54.82 & 380.70 & 116.04 \\
\hline 487.68 & 83.15 & 404.53 & 123.30 \\
\hline 492.74 & 91.92 & 400.82 & 122.17 \\
\hline 434.85 & 75.49 & 359.36 & 109.53 \\
\hline 483.74 & 94.18 & 389.56 & 118.74 \\
\hline
\end{tabular}

A. 5 
TABLE A.1. (contd)

Casing Depth to Water-Table Water-Table
Elevation,
Water, Elevation, Elevation,

We11 Date ft above MSL (a) ft $\mathrm{ft}$ above MSL m above MSL

$\begin{array}{llllll}699-S 19-E 13 & 06 / 19 / 90 & 394.51 & 45.87 & 348.64 & 106.27 \\ 699-\text { S29-E12 } & 06 / 19 / 90 & 387.96 & 40.81 & 347.15 & 105.81 \\ 699-\text { S30-E15A } & 06 / 19 / 90 & 400.14 & 52.63 & 347.51 & 105.92 \\ 699-\text { S31-1 } & 06 / 19 / 90 & 460.00 & 84.21 & 375.79 & 114.54\end{array}$

(a) MSL = mean sea level. 
APPENDIX B

WATER-LEVEL MEASUREMENTS FOR THE HANFORD SITE, DECEMBER 1990 


\section{APPENDIX B}

\section{WATER-LEVEL MEASUREMENTS FOR THE HANFORD SITE, DECEMBER 1990}

TABLE B.1. Hanford Site Water-Level Measurements in Unconfinéd Aquifer Wells, December 1990 (Measured by PNL Except as Noted)

\begin{tabular}{|c|c|c|c|c|c|}
\hline Well & Date & $\begin{array}{c}\text { Casing } \\
\text { Elevation, } \\
\mathrm{ft} \text { above } \mathrm{MSL}(\mathrm{a}) \\
\end{array}$ & $\begin{array}{c}\text { Depth to } \\
\text { Water, } \\
\mathrm{ft} \\
\end{array}$ & $\begin{array}{l}\text { Water-Level } \\
\text { Elevation, } \\
\mathrm{ft} \text { above MSL } \\
\end{array}$ & $\begin{array}{l}\text { Water-Table } \\
\text { Elevation, } \\
\text { m above MSL } \\
\end{array}$ \\
\hline $199-F 5-1$ & $12 / 21 / 90$ & 406.56 & 32.88 & 373.68 & 113.90 \\
\hline $299-E 13-10$ & $12 / 11 / 90$ & 738.84 & 334.83 & 404.01 & 123.14 \\
\hline $299-E 17-10$ & $12 / 13 / 90$ & 714.74 & 311.05 & 403.69 & 123.04 \\
\hline 299-E18-1 & $12 / 15 / 90$ & 720.24 & 315.81 & 404.43 & 123.27 \\
\hline $299-E$ & $12 / 21 / 90$ & 709.65 & 305.68 & 403.97 & 123.13 \\
\hline $299-E 25-11$ & $12 / 17 / 90$ & 681.28 & 277.32 & 403.96 & 123.13 \\
\hline $299-E 25-32 P$ & $12 / 17 / 90$ & 670.04 & 265.82 & 404.22 & 123.21 \\
\hline $299-E 25-34$ & $12 / 17 / 90$ & 662.87 & 258.63 & 404.24 & 123.21 \\
\hline $299-E 25-35$ & $12 / 17 / 90$ & 674.39 & 270.43 & 403.96 & 123.13 \\
\hline $299-E 26-1$ & $12 / 12 / 90$ & 617.25 & 212.74 & 404.51 & 123.29 \\
\hline 299-E27-9 & $12 / 11 / 90$ & 629.21 & 225.36 & 403.85 & 123.09 \\
\hline $299-E 28-27$ & $12 / 10 / 90$ & 680.37 & 276.75 & 403.62 & 123.02 \\
\hline $299-E 32-2$ & $12 / 10 / 90$ & 670.06 & 266.60 & 403.46 & 122.97 \\
\hline 299-E33-14 & $12 / 12 / 90$ & 622.12 & 218.14 & 403.98 & 123.13 \\
\hline $299-E 34-2$ & $12 / 11 / 90$ & 630.80 & 227.70 & 403.10 & 122.86 \\
\hline $299-E 34-5$ & $12 / 11 / 90$ & 590.79 & 186.11 & 404.68 & 123.35 \\
\hline 299-W19-1 & $12 / 21 / 90$ & 673.77 & 203.82 & 469.95 & 143.24 \\
\hline $699-03-45$ & $12 / 21 / 90$ & 504.54 & 92.93 & 411.61 & 125.46 \\
\hline $699-19-58$ & $12 / 18 / 90$ & 573.05 & 153.71 & 419.34 & 127.81 \\
\hline $699-19-88$ & $12 / 21 / 90$ & 644.45 & 131.27 & 513.18 & 156.42 \\
\hline $699-20-E 12$ & $12 / 17 / 90$ & 437.25 & 79.38 & 357.87 & 109.08 \\
\hline $699-24-33$ & $12 / 18 / 90$ & 524.21 & 121.65 & 402.56 & 122.70 \\
\hline $699-25-70$ & $12 / 18 / 90$ & 629.78 & 180.96 & 448.82 & 136.80 \\
\hline $699-29-78$ & $12 / 18 / 90$ & 647.05 & 183.38 & 463.67 & 141.33 \\
\hline $699-32-62$ & $12 / 18 / 90$ & 707.09 & 277.82 & 429.27 & 130.84 \\
\hline $699-32-70 B$ & $12 / 18 / 90$ & 666.68 & 214.81 & 451.87 & 137.73 \\
\hline $699-34-88$ & $12 / 18 / 90$ & 632.82 & 162.80 & 470.02 & 143.26 \\
\hline $699-35-9$ & $12 / 17 / 90$ & 499.83 & 113.37 & 386.46 & 117.79 \\
\hline $699-35-70$ & $12 / 18 / 90$ & 693.72 & 241.85 & 451.87 & 137.73 \\
\hline $699-35-78 A$ & $12 / 18 / 90$ & 660.65 & 194.02 & 466.63 & 142.23 \\
\hline $699-36-93$ & $12 / 21 / 90$ & 644.77 & 173.11 & 471.66 & 143.76 \\
\hline $699-39-39$ & $12 / 20 / 90$ & 536.65 & 124.25 & 412.40 & 125.70 \\
\hline $699-40-33 A$ & $12 / 20 / 90$ & 518.05 & 106.96 & 411.09 & 125.30 \\
\hline $699-43-89$ & $12 / 18 / 90$ & 644.15 & 177.05 & 467.10 & 142.37 \\
\hline $699-45-69 A$ & $12 / 21 / 90$ & 725.46 & 277.51 & 447.95 & 136.54 \\
\hline 69 & $12 / 17 / 90$ & 522.02 & 130.34 & 391.68 & 119.38 \\
\hline 69 & $12 / 21 / 90$ & 476.36 & 62.62 & 413.74 & 126.11 \\
\hline $699-47$ & $12 / 21 / 90$ & 580.14 & 175.21 & 404.93 & 123.42 \\
\hline
\end{tabular}


TABLE B.1. (contd)

\begin{tabular}{|c|c|c|c|c|c|}
\hline Well & Date & $\begin{array}{l}\text { Elevation, } \\
\mathrm{ft} \text { above MSL }\end{array}$ & $\begin{array}{c}\text { Water, } \\
\mathrm{ft}\end{array}$ & $\begin{array}{l}\text { Elevation, } \\
\mathrm{ft} \text { above MSL }\end{array}$ & $\begin{array}{l}\text { Elevation, } \\
\text { m above MSI }\end{array}$ \\
\hline $699-50-42$ & $12 / 20 / 90$ & 466.84 & 55.70 & 411.14 & 125.32 \\
\hline $699-50-85$ & $12 / 18 / 90$ & 739.35 & 282.90 & 456.45 & 139.13 \\
\hline $699-51-63$ & $12 / 19 / 90$ & 571.84 & 166.13 & 405.71 & 123.66 \\
\hline $699-51-75$ & $12 / 19 / 90$ & 641.51 & 191.55 & 449.96 & 137.15 \\
\hline $699-53-35$ & $12 / 20 / 90$ & 530.99 & 132.62 & 398.37 & 121.42 \\
\hline $699-55-21$ & $12 / 20 / 90$ & 395.96 & 34.98 & 360.98 & 110.03 \\
\hline $699-55-89$ & $12 / 19 / 90$ & 617.43 & 162.84 & 454.59 & 138.56 \\
\hline $699-55-95$ & $12 / 21 / 90$ & 777.05 & 311.42 & 465.63 & 141.92 \\
\hline $699-57-83 A$ & $12 / 19 / 90$ & 577.96 & 145.00 & 432.96 & 131.97 \\
\hline $699-61-37$ & $12 / 20 / 90$ & 442.94 & 60.87 & 382.07 & 116.45 \\
\hline $699-63-51$ & $12 / 20 / 90$ & 424.54 & 24.18 & 400.36 & 122.03 \\
\hline $699-63-90$ & $12 / 19 / 90$ & 509.73 & 110.37 & 399.36 & 121.72 \\
\hline $699-65-72$ & $12 / 19 / 90$ & 540.28 & 140.61 & 399.67 & 121.82 \\
\hline $699-66-23$ & $12 / 20 / 90$ & 389.01 & 25.68 & 363.33 & 110.74 \\
\hline $699-66-38$ & $12 / 21 / 90$ & 436.20 & 33.81 & 402.39 & 122.65 \\
\hline $699-66-103$ & $12 / 19 / 90$ & 463.01 & 62.93 & 400.08 & 121.94 \\
\hline $699-69-38$ & $12 / 21 / 90$ & 422.93 & 21.72 & 401.21 & 122.29 \\
\hline $699-71-77$ & $12 / 19 / 90$ & 472.28 & 74.40 & 397.88 & 121.27 \\
\hline $699-72-92$ & $12 / 19 / 90$ & 452.22 & 50.95 & 401.27 & 122.31 \\
\hline $699-73-61$ & $12 / 20 / 90$ & 531.53 & 131.71 & 399.82 & 121.87 \\
\hline $699-74-44$ & $12 / 21 / 90$ & 445.18 & 48.35 & 396.83 & 120.95 \\
\hline $699-77-36$ & $12 / 21 / 90$ & 412.28 & 36.22 & 376.06 & 114.62 \\
\hline $699-86-42$ & $12 / 21 / 90$ & 409.92 & 25.12 & 384.80 & 117.29 \\
\hline $699-87-55$ & $12 / 20 / 90$ & 458.63 & 70.96 & 387.67 & 118.16 \\
\hline $699-97-43$ & $12 / 21 / 90$ & 421.81 & 42.28 & 379.53 & 115.68 \\
\hline $699-S 6-E 40$ & $12 / 17 / 90$ & 430.47 & 57.92 & 372.55 & 113.55 \\
\hline $699-58-19$ & $12 / 18 / 90$ & 503.81 & 106.80 & 397.01 & 121.01 \\
\hline $699-\$ 31-1$ & $12 / 17 / 90$ & 460.11 & 84.17 & 375.94 & 114.59 \\
\hline
\end{tabular}

(a) $\mathrm{MSL}=$ mean sea level.

(b) Measured by WHC. 
APPENDIX C

WATER-LEVEL MEASUREMENTS AT SPECIFIC HANFORD SITE AREAS, JUNE 1990 


\section{APPENDIX C}

WATER-LEVEL MEASUREMENTS AT SPECIFIC HANFORD SITE AREAS, JUNE 1990

TABLE C.1. Decommissioned 216-U-10 Pond Water-Leve1 Measurements in Unconfined Aquifer Wells, June 1990 (Measured by PNL)

\begin{tabular}{|c|c|c|c|c|c|}
\hline Well & Date & $\begin{array}{c}\text { Casing } \\
\text { Elevation, (a) } \\
\mathrm{ft} \text { above MSL (a) } \\
\end{array}$ & $\begin{array}{l}\text { Depth to } \\
\text { Water, } \\
\mathrm{ft} \\
\end{array}$ & $\begin{array}{c}\text { Water-Table } \\
\text { Elevation, } \\
\mathrm{ft} \text { above MSL } \\
\end{array}$ & $\begin{array}{l}\text { Water-Table } \\
\text { Elevation, } \\
\text { m above MSL }\end{array}$ \\
\hline $299-W 10-05$ & $06 / 19 / 90$ & 672.31 & 205.78 & 466.53 & 142.20 \\
\hline $299-h$ & $06 / 19 / 90$ & 699.04 & 233.38 & 465.66 & 141.93 \\
\hline $299-$ & $06 / 19 / 90$ & 728.89 & 271.89 & 457.00 & 139.29 \\
\hline 299 - & $06 / 19 / 90$ & 662.00 & 193.13 & 468.87 & 142.91 \\
\hline $299-1$ & $06 / 18 / 90$ & 697.96 & 230.04 & 467.92 & 142.62 \\
\hline $299-1$ & $06 / 18 / 90$ & 684.89 & 216.14 & 468.75 & 142.88 \\
\hline $299-1$ & $06 / 18 / 90$ & 660.76 & 191.39 & 469.37 & 143.06 \\
\hline 299 & $06 / 18 / 90$ & 668.62 & 200.52 & 468.10 & 142.68 \\
\hline 29 & $06 / 1$ & 696.81 & 228.70 & 468.11 & 142.68 \\
\hline $299-W$ & $06 / 1$ & .35 & 14 & 469.21 & 143.02 \\
\hline 299 & $06 / 18 / 90$ & 673.77 & 202.37 & 471.40 & 143.68 \\
\hline 299 & $06 / 18 / 90$ & .26 & 254.78 & 460.48 & 140.35 \\
\hline 299-W19-13 & $06 / 18 / 90$ & .08 & 230.17 & 464.91 & 141.70 \\
\hline $299-W 21-01$ & $06 / 18 / 90$ & .26 & 243.37 & 455.89 & 138.96 \\
\hline $299-W 22-08$ & $06 / 18 / 90$ & .55 & 225.44 & 458.11 & 139.63 \\
\hline 299-W23-11 & $06 / 13 / 90$ & 664.14 & 197.89 & 466.25 & 142.11 \\
\hline $699-32-70 B$ & $06 / 13 / 90$ & 666.68 & 214.94 & 451.74 & 137.69 \\
\hline $699-32-72$ & $06 / 13 / 90$ & 668.16 & 214.13 & 454.03 & 138.39 \\
\hline $699-32-77$ & $06 / 13 / 90$ & 653.74 & 191.50 & 462.24 & 140.89 \\
\hline $699-35-78 A$ & $06 / 13 / 90$ & 660.65 & 193.79 & 466.86 & 142.30 \\
\hline $699-37-82 A$ & $06 / 13 / 90$ & 636.75 & 169.21 & 467.54 & 142.51 \\
\hline & $06 / 15 / 90$ & 710.67 & & 453.74 & 138.30 \\
\hline $699-3$ & $06 / 19 / 90$ & 673.52 & 205.76 & 467.76 & 142.57 \\
\hline
\end{tabular}

(a) $M S L=$ mean sea level. 
TABLE C.2. 216-B-3 Pond Water-Level Measurements in Unconfined Aquifer Wel1s, June 1990 (Measured by WHC)

\begin{tabular}{|c|c|c|c|c|c|}
\hline Well & Date. & $\begin{array}{c}\text { Casing } \\
\text { Elevation, } \\
\mathrm{ft} \text { above MSL (a) } \\
\end{array}$ & $\begin{array}{c}\text { Depth to } \\
\text { Water, } \\
\mathrm{ft} \\
\end{array}$ & $\begin{array}{c}\text { Water-Table } \\
\text { Elevation, } \\
\mathrm{ft} \text { above MSL }\end{array}$ & $\begin{array}{r}\text { Water-Table } \\
\text { Elevation, } \\
\text { m above MSL }\end{array}$ \\
\hline $299-E 25-32 P$ & $06 / 11 / 90$ & 669.19 & 263.49 & 405.70 & 123.66 \\
\hline $699-39-39$ & $06 / 11 / 90$ & 536.65 & 123.54 & 413.11 & 125.92 \\
\hline $699-40-33 A$ & $06 / 11 / 90$ & 518.05 & 106.73 & 411.32 & 125.37 \\
\hline $699-40-39$ & $06 / 11 / 90$ & 541.84 & 128.07 & 413.77 & 126.12 \\
\hline $699-41-40$ & $06 / 11 / 90$ & 545.94 & 129.58 & 416.36 & 126.91 \\
\hline $699-42-40 B$ & $06 / 11 / 90$ & 546.46 & 124.35 & 422.11 & 128.66 \\
\hline $699-43-41 E$ & $06 / 11 / 90$ & 550.86 & 129.57 & 421.29 & 128.41 \\
\hline $699-43-42 J$ & $06 / 11 / 90$ & 581.68 & 162.46 & 419.22 & 127.78 \\
\hline $699-43-43$ & $06 / 11 / 90$ & 579.37 & 164.20 & 415.17 & 126.54 \\
\hline $699-43-45$ & $06 / 11 / 90$ & 597.68 & 192.10 & 405.58 & 123.62 \\
\hline $699-44-42$ & $06 / 11 / 90$ & 579.22 & 158.32 & 420.90 & 128.29 \\
\hline $699-44-43 B$ & $06 / 14 / 90$ & 580.12 & 164.42 & 415.70 & 126.71 \\
\hline $699-45-42$ & $06 / 14 / 90$ & 577.33 & 159.74 & 417.59 & 127.28 \\
\hline $699-47-35 A$ & $06 / 14 / 90$ & 476.36 & 62.17 & 414.19 & 126.25 \\
\hline $699-47-46 A$ & $06 / 14 / 90$ & 580.14 & 174.74 & 405.40 & 123.57 \\
\hline
\end{tabular}

(a) $M S L=$ mean sea level. 
TABLE C.3. 100-N Area Water-Level Measurements in Unconfined Aquifer We11s, June 22, 1990 (Measured by WHC)

\begin{tabular}{|c|c|c|c|c|}
\hline Well & $\begin{array}{c}\text { Casing } \\
\text { Elevation, } \\
\mathrm{ft} \text { above MSL (a) } \\
\end{array}$ & $\begin{array}{l}\text { Depth to } \\
\text { Water, } \\
\mathrm{ft} \\
\end{array}$ & $\begin{array}{c}\text { Water-Table } \\
\text { Elevation, } \\
\mathrm{ft} \text { above MSL } \\
\end{array}$ & $\begin{array}{l}\text { Water-Table } \\
\text { Elevation, } \\
\text { m above MSL } \\
\end{array}$ \\
\hline $199-\mathrm{N}-02$ & 459.83 & 68.27 & 391.56 & 119.35 \\
\hline $199-N-03$ & 459.45 & 67.78 & 391.67 & 119.38 \\
\hline $199-N-04$ & 458.73 & 67.03 & 391.70 & 119.39 \\
\hline $199-N-06$ & 460.97 & 68.42 & 392.55 & 119.65 \\
\hline $199-N-8 S$ & 404.57 & 14.76 & 389.81 & 118.81 \\
\hline $199-N-14$ & 453.15 & 63.03 & 390.12 & 118.91 \\
\hline $199-N-16$ & 456.70 & 64.82 & 391.88 & 119.45 \\
\hline $199-\mathrm{N}-17$ & 461.20 & 69.85 & 391.35 & 119.28 \\
\hline $199-N-18$ & 458.50 & 67.45 & 391.05 & 119.19 \\
\hline $199-N-19$ & 453.90 & 62.73 & 391.17 & 119.23 \\
\hline $199-N-20$ & 455.90 & 64.38 & 391.52 & 119.34 \\
\hline $199-N-21$ & 457.00 & 65.58 & 391.42 & 119.30 \\
\hline $199-\mathrm{N}-23$ & 456.30 & 65.11 & 391.19 & 119.23 \\
\hline $199-\mathrm{N}-24$ & 432.50 & 41.41 & 391.09 & 119.20 \\
\hline $199-\mathrm{N}-25$ & 425.80 & 34.59 & 391.21 & 119.24 \\
\hline $199-N-26$ & 455.80 & 64.58 & 391.22 & 119.24 \\
\hline $199-N-27$ & 449.08 & 57.14 & 391.94 & 119.46 \\
\hline $199-N-28$ & 464.24 & 71.78 & 392.46 & 119.62 \\
\hline $199-N-29$ & 465.25 & 72.73 & 392.52 & 119.64 \\
\hline $199-N-31$ & 462.63 & 70.82 & 391.81 & 119.42 \\
\hline $199-N-32$ & 462.08 & 70.21 & 391.87 & 119.44 \\
\hline $199-N-33$ & 459.87 & 68.16 & 391.71 & 119.39 \\
\hline $199-N-34$ & 459.63 & 67.59 & 392.04 & 119.49 \\
\hline $199-N-36$ & 458.97 & 67.41 & 391.56 & 119.35 \\
\hline $199-N-37$ & 456.12 & 64.81 & 391.31 & 119.27 \\
\hline $199-\mathrm{N}-39$ & 454.31 & 63.38 & 390.93 & 119.16 \\
\hline $199-N-40$ & 456.35 & 65.92 & 390.43 & 119.00 \\
\hline $199-N-41$ & 457.59 & 67.70 & 389.89 & 118.84 \\
\hline $199-N-42$ & 455.14 & 65.24 & 389.90 & 118.84 \\
\hline $199-N-44$ & 460.70 & 69.69 & 391.01 & 119.18 \\
\hline $199-N-49$ & 450.72 & 60.80 & 389.92 & 118.85 \\
\hline $199-\mathrm{N}-50$ & 453.36 & 73.80 & 379.56 & 115.69 \\
\hline $199-N-51$ & 462.18 & 72.72 & 389.46 & 118.71 \\
\hline $199-N-52$ & 463.70 & 71.48 & 392.22 & 119.55 \\
\hline $199-N-53$ & 461.76 & 71.10 & 390.66 & 119.07 \\
\hline $199-\mathrm{N}-54$ & 457.51 & 65.75 & 391.76 & 119.41 \\
\hline $199-N-55$ & 457.85 & 66.08 & 391.77 & 119.41 \\
\hline $199-\mathrm{N}-56$ & 458.09 & 66.68 & 391.41 & 119.30 \\
\hline $199-N-57$ & 457.76 & 65.67 & 392.09 & 119.51 \\
\hline $199-N-58$ & 462.88 & 70.49 & 392.39 & 119.60 \\
\hline $199-N-59$ & 459.53 & 67.17 & 392.36 & 119.59 \\
\hline $199-N-60$ & 461.94 & 69.53 & 392.41 & 119.61 \\
\hline
\end{tabular}


TABLE C.3. (contd)

Casing Depth to Water-Table Water-Table

Elevation, Water, Elevation, Elevation,

Wel1 $\mathrm{ft}$ above MSL (a) $\mathrm{ft}$ ft above MSL m above MSL

$199-\mathrm{N}-61$

462.02 ' Well is Dry

$199-N-62$

$199-\mathrm{N}-63$

$199-\mathrm{N}-64$

$199-N-65$

$199-\mathrm{N}-66$

$199-N-67$

463.59

466.70

71.12

74.48

62.57

454.63

456.44

64.58

465.25

73.50

458.46

67.37

Hanford Generating

Plant (HGP) (River Stage Elevation)

392.47

392.22

119.62

119.55

119.50

119.44

119.41

119.20

391.09

118.72

(a) $M S L=$ mean sea level. 
TABLE C.4. 300 Area Water-Level Measurements in Unconfined Aquifer Wells, June 25, 1990 (Measured by WHC)

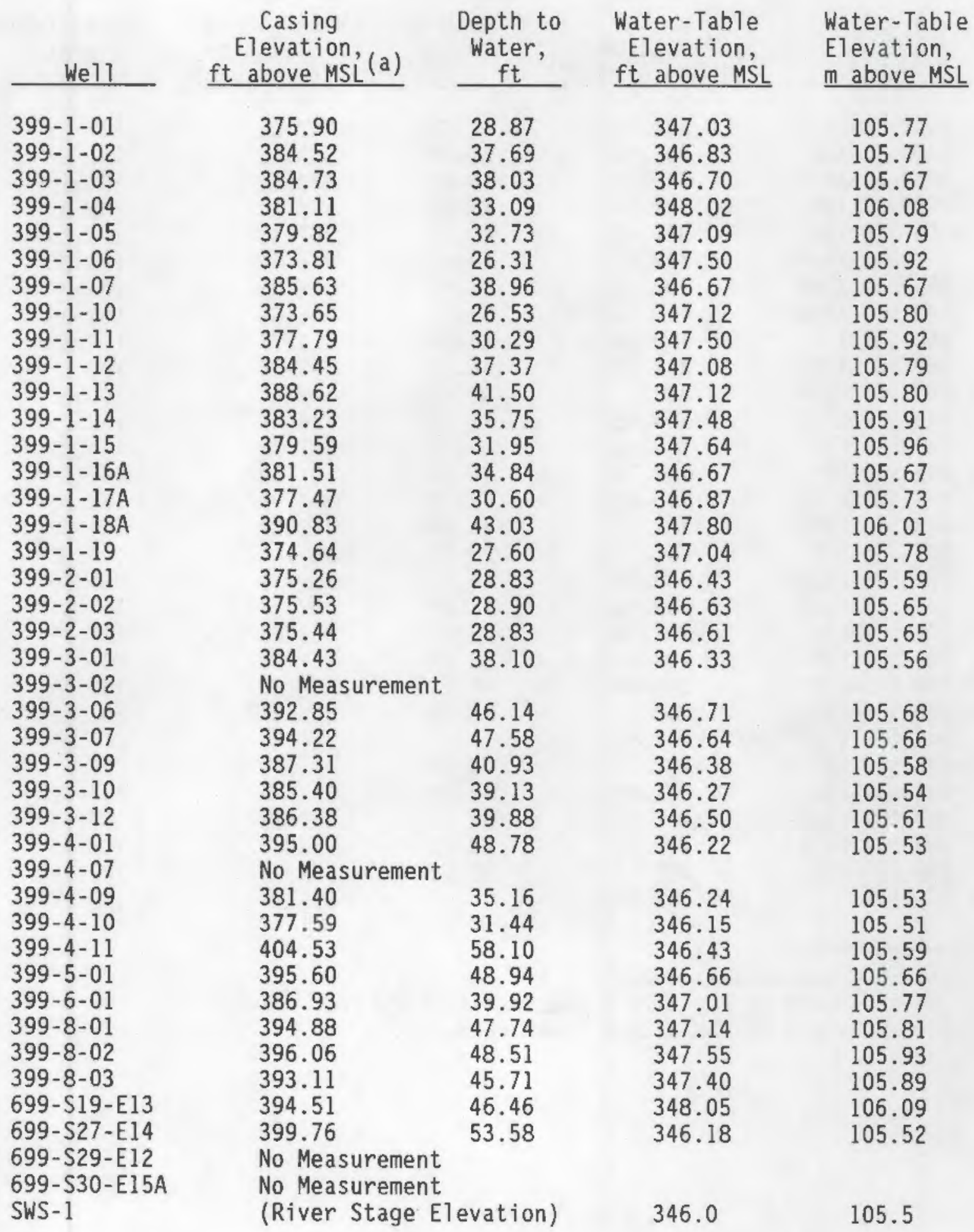

(a) $M S L=$ mean sea level. 
TABLE C.5. 1100 and 3000 Areas Water-Level Measurements in Unconfined Aquifer Wells, June 27, 1990 (Measured by WHC)

\begin{tabular}{|c|c|c|c|c|}
\hline Well & $\begin{array}{c}\text { Casing } \\
\text { Elevation, } \\
\mathrm{ft} \text { above MSL (a) } \\
\end{array}$ & $\begin{array}{c}\text { Depth to } \\
\text { Water, } \\
\mathrm{ft}\end{array}$ & $\begin{array}{c}\text { Water-Table } \\
\text { Elevation, } \\
\mathrm{ft} \text { above MSL }\end{array}$ & $\begin{array}{l}\text { Water-Table } \\
\text { Elevation, } \\
\text { m above MSL }\end{array}$ \\
\hline $1199-34-13$ & 394.78 & 42.77 & 352.01 & 107.29 \\
\hline $1199-41-13 C$ & 405.98 & 52.90 & 353.08 & 107.62 \\
\hline $3099-45-16$ & 408.04 & 59.65 & 348.39 & 5.106 .19 \\
\hline $3099-47-18 B$ & 374.95 & 27.61 & 347.34 & 105.87 \\
\hline $699-S 29-E 12$ & 387.96 & 40.64 & 347.32 & 105.86 \\
\hline $699-S 30-E 10 A$ & 392.29 & 43.61 & 348.68 & 106.28 \\
\hline $699-$ S30-E 108 & 392.07 & 43.02 & 349.05 & 106.39 \\
\hline $699-S 30-E 15 A$ & 400.14 & 53.51 & 346.63 & 105.65 \\
\hline $699-531-1$ & 460.00 & 84.23 & 375.77 & 114.53 \\
\hline 699-S31-E10A & 384.57 & 36.29 & 348.28 & 106.16 \\
\hline 699-S31-E1OB & 383.71 & 34.85 & 348.86 & 106.33 \\
\hline $699-S 31-E 100$ & 380.58 & 31.89 & 348.69 & 106.28 \\
\hline $699-S 31-E 13$ & 394.06 & 46.30 & 347.76 & 106.00 \\
\hline $699-\mathrm{S} 31-\mathrm{E} 8$ & 374.75 & 21.76 & 352.99 & 107.59 \\
\hline 699-S32-E13A & 390.46 & 42.53 & 347.93 & 106.05 \\
\hline $699-S 32-E 13 B$ & 394.72 & 46.70 & 348.02 & 106.08 \\
\hline $699-\mathrm{S} 34-\mathrm{E} 10$ & 382.37 & 29.91 & 352.46 & 107.43 \\
\hline 699-S36-E12B & 399.04 & 46.72 & 352.32 & 107.39 \\
\hline $699-S 36-E 13 A$ & 399.30 & 47.03 & 352.27 & 107.37 \\
\hline 699-S37-E11 & 399.30 & 46.87 & 352.43 & 107.42 \\
\hline $699-537-E 14$ & 408.28 & 55.89 & 352.39 & 107.41 \\
\hline $699-538-E 11$ & 398.60 & 45.73 & 352.87 & 107.55 \\
\hline $699-S 38-E 12 A$ & 404.95 & 52.08 & 352.87 & 107.55 \\
\hline $699-S 40-E 14(\mathrm{~b})$ & 402.85 & - & 354.63 & 108.09 \\
\hline 699-S41-Ell & 401.36 & 48.27 & 353.09 & 107.62 \\
\hline 699-S41-E12 & 401.93 & 49.49 & 352.44 & 107.42 \\
\hline $699-S 41-E 13 A$ & 410.56 & 56.77 & 353.79 & 107.84 \\
\hline 699-S41-El3B & 410.10 & 56.27 & 353.83 & 107.85 \\
\hline $699-\$ 43-E 12$ & 405.60 & 52.66 & 352.94 & 107.58 \\
\hline$E C-1$ & 362.57 & - & 355.22 & 108.27 \\
\hline
\end{tabular}

(a) $\mathrm{MSL}=$ mean sea level.

(b) Measured by PNL with a pressure transducer.

(c) Measured by PNL with a float recorder. 


\section{DISTRIBUTION}

No. of

Copies

OFFSITE

2 DOE/Office of Scientific and Technical Information

\section{ONSITE}

23 DOE-Richland Operations office

G. M. Bell

R. D. Hildebrand

R. G. Holt

M. W. Tiernan (20)

17 Westinghouse Hanford Company

M. R. Adams

L. C. Brown

G. D. Carpenter

M. A. Christie

C. D. Delaney

L. P. Diedicker

J. J. Dorian

K. R. Fecht

K. A. Gano

E. M. Greager

R. L. Jackson

G. L. Kasza

A. G. Law

D. L. Lund

J. A. Serkowski

L. C. Swanson

Public Reading Room
No. of

Copies

\section{Pacific Northwest Laboratory}

D. J. Bates

J. V. Borghese

R. W. Bryce

M. A. Chamness

J. C. Evans

J. W. Falco

M. D. Freshley (Mark)

R. M. Frul and

T. J Gilmore

S. M. Goodwin

W. R. Gorst

R. H. Gray (2)

J. M. Hales

S. H. Hall

P. C. Hays

P. E. Long

S. P. Luttrell

J. P. McDonald

R. W. Nelson

D. R. Newcomer (20)

W. T. Pennell

K. D. Pohlod

J. T. Rieger

L. E. Rogers

R. Schalla

R. E. Skaggs

S. S. Teel

P. D. Thorne

R. W. Wallace

E. J. Westergard Publishing Coordination Technical Report Files (5) 

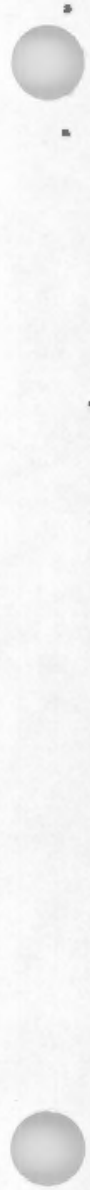

- 



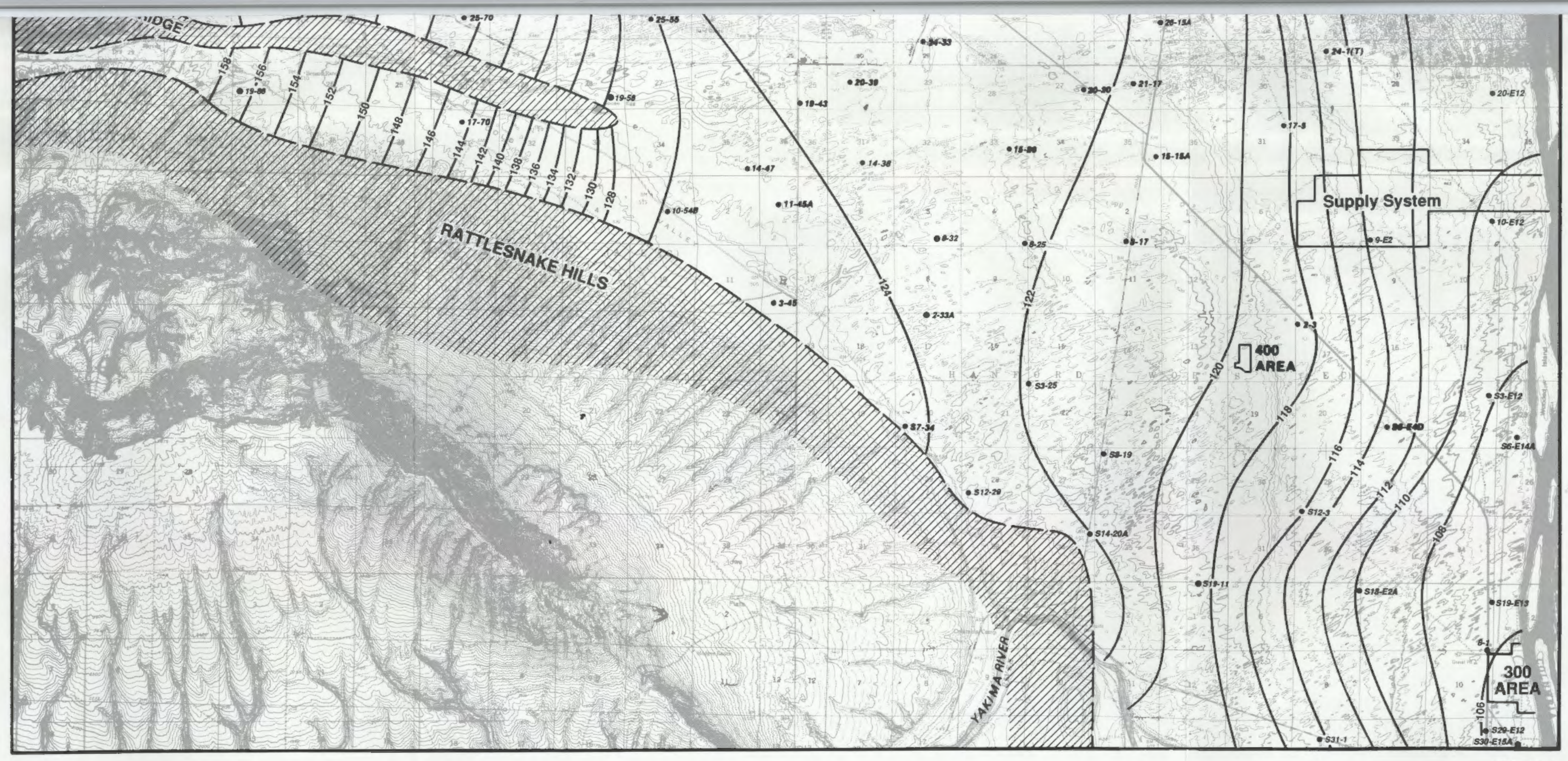

$\frac{1043^{\prime}}{31 \text { MILS }} \mid \frac{21^{\circ}}{373 \text { MILS }}$

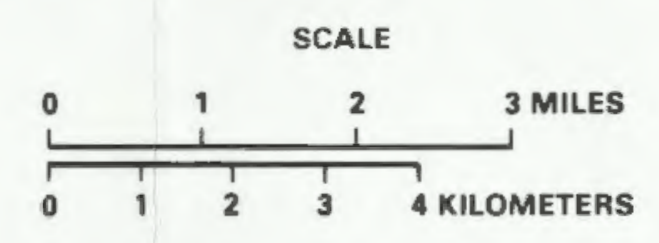

UTM GRID AND 1951

DECLINATION AT

CENTER OF SHEET
WELLS USED IN PPEPARATION OF MAP. WELL PUEFIX 199 REMAINING WELLS HAVE THE PAEFIX 699.

PONOS, WATER-SURFACE ELEVATION IN METERS

ABOVE MEAN SEA LEVEL

DTTT GENERALIZED OUTCROP OF BASALT ABOVE THE WATER TABLE

WATER-TABLE CONTOUR IN METERS ABOVE MEAN SEA LEVEL (CONTOUA INTERVAL =
2 METEFS)
TO CONVERT METERS TO FEET,

DIVIDE BY 0.3048.

BASE MAPS ARE PORTIONS OF HANFORD, COYOTE AAPIDS. RICHLAND, AND CORRAL 15' US. DEPARTMENT OF THE INTERIOA, GEOLOGICAL SURVEY 